\title{
THE EPIDEMIOLOGY OF CORONARY HEART DISEASE
}

\author{
A REVIEW
}

FREDERICK H. EPSTEIN, M.D.

Department of Epidemiology, University of Michigan, School of Public Health, Ann Arbor, Michigan

The Proceedings of the First National Conference on Cardiovascular Diseases in 1950 include a brief review of epidemiology. In referring specifically to the 'degenerative' cardiovascular diseases, LANGMUIR [1] stated : " . . epidemiology has contributed little other than to help in defining the problem, and to assist in planning facilities to meet it." Viewed against this blunt and fair appraisal of the situation at the time, knowledge of the epidemiology of coronary heart disease has, indeed, made remarkable strides in the 15 relatively short years that have since passed. In fact, looking over the history of medicine, few fields seem to have made such rapid progress over so brief a span of time. As a result, DAWBER and KANNEL [2], referring to coronary disease, have rightly stated: "It has seldom been possible in noninfectious diseases to identify ... highly susceptible individuals years before the development of disease." When new fields of research come into their own with such sudden force, the time is usually ripe for several reasons and no isolated influence can be singled out to account for the phenomenon. Concerning the epidemiology of coronary heart disease, however, reference must be made to the intellectual, apart from the financial stimulus which came from the National Heart Institute, illustrated by Dr. JAMES WATT in an address on "Arteriosclerosis and Epidemiology", presented before the American Society for the Study of Arteriosclerosis in 1953 [3]. Another landmark was the "Conference on Epidemiology of Atherosclerosis and Hypertension", at Arden House in 1956, under the auspices of the American Heart Association and the National Heart Institute [4]. These two agencies again took the lead in sponsoring, in 1959, the conference on "Epidemiology of Cardiovascular Disease Methodology" in Princeton [5]. Concurrently, the World Health Organization set up a division of Cardiovascular Diseases which has made a number of important contributions to the field of epidemiology [6-8]. Other national and international groups, not to mention individual leaders, have played decisive roles in these developments but it is the purpose of this review to summarize the achievements rather than the organization of epidemiological research in coronary heart disease. Nevertheless, it seemed appropriate to mention at least some of these undercurrents since epidemiological investigations especially call for collaborative efforts and interchanges concerning research organization and design [9].

This revicw will be confined to the epidemiological features of coronary heart disease as they present themselves in studies among human population groups. Other reviews have appeared in recent years [10-22]. Epidemiology is more properly regarded as a field of activity which embraces, in addition, clinical and laboratory investigations as they tie into population studies [15]. These aspects will, however, be 
considered elsewhere as part of the National Conference so that a more narrow definition of epideminlogy will be used for the purpose of this review. The literature in this field has grown to such proportions that it will be impossible to be comprehensive and include all references or to discuss all facets of the problem. Some relevant and important contributions will be missed while others are being quoted to illustrate the issue rather than to provide an exhaustive documentation.

\section{MORTALITY STATISTICS}

The recent advances in coronary heart disease epidemiology are largely due to the fact that field studies among living populations have gained ascendance over information from mortality statistics (sometimes euphemistically called 'vital' statistics) which had, for many years, been the only source of information on the distribution of this disease. Nevertheless, mortality statistics rcmain onc important area of research and yield data which cannot be obtained in any other way. At the same time, great efforts are being made to improve the accuracy of diagnoses on death certificates $[23,24]$; a recent careful study has revealed that an entry of 'arteriosclerotic heart disease' in a sample of certificates from the United States is often poorly substantiated [25]. Similarly, a considerable proportion of such entries is based on unattended deaths without autopsy confirmation [26]. In spite of these problems, it is rewarding to review the data, providing their limitations are kept in mind.

\section{United States}

Beyond middle-age, the mortality trend from cardiovascular-renal diseases has remained steady or decreased somewhat over the past decades [27]. Mortality from arteriosclerotic heart disease, by contrast, has increased [21, 20] and it is likely that this increase is largely real [21]. In fact, the view that coronary heart disease is due, to a considerable degree, to environmental influences is based in part on this observation. Between 1950 and 1960, however, deaths from this disease have increased at a lesser rate, amounting to 4.3 per cent over this period for white men aged 45-64 years [28]. It is reassuring that the increase has been less in recent years but this is no ground for gratification since the death rate from this disease in 1950 was already so high that it is hard to conceive how it could have increased much further. Indeed, it is rather surprising that such importance has been given to the fact that the total death rate from all cardiovascular-renal diseases in middle-aged men has decreased some 6 per cent between 1950 and 1960, suggesting that the tide has turned [28]. That this view is premature may be demonstrated by taking the population of white men, aged 45-64 in 1950 , as the denominator and applying to it the death rates obtained from several sources $[29,30]$, in the relevant categories in 1950 and 1960 (Table 1). In this way, the actual number of deaths in 1950 may be compared with the numbers which would have been expected if the 1960 rates had prevailed in 1950. It will be seen that 7228 fewer deaths from the major cardiovascular-renal diseases would have occurred in 1950 if the 1960 rates had applied. At the same time, it is apparent that the increase in deaths from arteriosclerotic heart disease is about balanced by a decrease in deaths from hypertensive disease and vascular lesions affecting the central nervous system. Thus, there is no real change in the total frequency of deaths from the consequences of arteriosclerosis and hypertension; the overall decrease for the major cardiovascularrenal diseases is accounted for by a decline in deaths from other types of cardiovascular- 


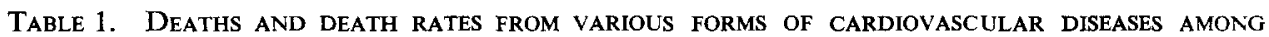
WHITE MEN AGED 45-64 IN THE UNITED STATES: COMPARISON BETWEEN OBSERVED DEATHS IN 1950 AND DEATHS WHICH WOULD HAVE BEEN EXPECTED IN 1950 IF THE RATES PREVAILING IN 1960 HAD APPLIED

\begin{tabular}{|c|c|c|c|c|c|c|c|}
\hline \multirow[t]{2}{*}{ Cat egory } & \multirow[t]{2}{*}{ Age } & \multirow{2}{*}{$\begin{array}{c}\text { Population } \\
\text { in } 1950\end{array}$} & \multicolumn{2}{|c|}{$\begin{array}{l}\text { Death rate } \\
\text { per } 100,000 \text { in: }\end{array}$} & \multicolumn{2}{|c|}{$\begin{array}{l}\text { Number of deaths } \\
\text { in } 1950\end{array}$} & \multirow{2}{*}{$\begin{array}{c}\text { Difference } \\
\text { between } \\
\text { observed } \\
\text { and ex- } \\
\text { pected nos. }\end{array}$} \\
\hline & & & 1950 & 1960 & Observed & Expected & \\
\hline $\begin{array}{l}\text { Major cardio- } \\
\text { vascular-renal } \\
\text { diseases }\end{array}$ & $\begin{array}{l}45-54 \\
55-64 \\
45-64\end{array}$ & $\begin{array}{l}7,836,299 \\
6,180,287\end{array}$ & $\begin{array}{r}508.1 \\
1337.3\end{array}$ & $\begin{array}{r}477.5 \\
1258.5\end{array}$ & $\begin{array}{r}39,815 \\
82,648 \\
122,463\end{array}$ & $\begin{array}{r}37,418 \\
77,790 \\
115,208\end{array}$ & -7255 \\
\hline $\begin{array}{l}\text { Arteriosclerotic } \\
\text { heart disease }\end{array}$ & $\begin{array}{l}45-54 \\
55-64 \\
45-64\end{array}$ & $\begin{array}{l}7,836,299 \\
6,180,287\end{array}$ & $\begin{array}{l}323.1 \\
812.9\end{array}$ & $\begin{array}{l}352.5 \\
901.3\end{array}$ & $\begin{array}{l}25,317 \\
50,238 \\
75,555\end{array}$ & $\begin{array}{l}27,623 \\
55,703 \\
83,326\end{array}$ & +7771 \\
\hline $\begin{array}{l}\text { Hypertensive } \\
\text { heart disease }\end{array}$ & $\begin{array}{l}45-54 \\
55-64 \\
45-64\end{array}$ & $\begin{array}{l}7,836,299 \\
6,180,287\end{array}$ & $\begin{array}{r}33.8 \\
105.8\end{array}$ & $\begin{array}{l}14.9 \\
52.3\end{array}$ & $\begin{array}{l}2,651 \\
6,540 \\
9,191\end{array}$ & $\begin{array}{l}1,168 \\
3,232 \\
4,400\end{array}$ & -4791 \\
\hline $\begin{array}{c}\text { Vascular lesions } \\
\text { affecting CNS }\end{array}$ & $\begin{array}{l}45-54 \\
55-64 \\
45-64\end{array}$ & $\begin{array}{l}7,836,299 \\
6,180,287\end{array}$ & $\begin{array}{r}53.7 \\
182.2\end{array}$ & $\begin{array}{r}40.9 \\
139.0\end{array}$ & $\begin{array}{r}4,208 \\
11,260 \\
15,468\end{array}$ & $\begin{array}{r}3,205 \\
8,591 \\
11,796\end{array}$ & -3672 \\
\hline
\end{tabular}

renal diseases. Also, in terms of numbers rather than rates the lives saved are, indecd, few among these particular men. This is particularly relevant if it is recalled that no less than one-third of all deaths among white men in the United States between the ages of 1 and 65 are due to arteriosclerotic heart disease. It is concluded that, in terms of mortality, no gains in the control of coronary heart disease have been made since 1950. This actually would not have been expected since there has been no large-scale effort to control the factors which are thought to predispose to this disease.

In contrast to the national picture, death rates from arteriosclerotic heart disease in California among white men have declined slightly in the 1950's; among Negro men, however, the corresponding rates have risen quite steeply [31]. National data have likewise shown that the rise in death rates from arteriosclerotic heart disease has been more marked among non-white men [30]. This important epidemiological finding calls for a detailed comparison of rates in various states or regions. Death rates from other causes are also high among Negroes [32]. The increase in arteriosclerotic heart disease mortality has been greatest in states where the rates were initially lowest, especially in the South [26]; the possibility that this pattern in is part accounted for by changing fashions of death certification must be kept in mind and would particularly apply to the Negro population.

Deaths from the major cardiovascular-renal diseases in the country as a whole have declined for women as well as for men [27]. Those from artcriosclerotic heart disease, however, have risen in women, as in men, in both the non-white and white groups [30]. Since the rates in women are lower than in men, the numbers on which some of these changes in rates are based are relatively small so that slight variations over time on the mode of death certification could affect these rates appreciably. The trend of mortality among women over the next decade will be followed with great interest, especially among non-white women who show higher arteriosclerotic heart disease rates than white women aged up to 75 years [33]. 
Variations in arteriosclerotic heart disease mortality between the various states continue to be intriguing and unexplained. There can be little doubt that the observed differences are, at least in part, real [34]. While rates are higher in metropolitan than non-metropolitan areas, these trends are not entirely accounted for by differences in urbanization, though variations within the State of New York seem to be associated with an urban-rural gradient [35-37]. Preliminary observations suggest that persons born in 'high mortality' states carry with them a high mortality from arteriosclerotic heart disease even when they die in a 'low-mortality' state, and vice versa [38]. If confirmed, these data would provide a striking demonstration of the importance of influences in early life on the later development of chronic disease.

On the basis of mortality data, areas of high and low risk within the United States have been identified [38]. Field studies in these areas are being instituted, in order to verify these differences and discover their causes [39].

\section{International trends and comparisons}

It has been recognized for many years that the mortality from the arteriosclerotic diseases varies from country to country [40]. The need to buttress these suggestions with data from field studies was recognized with particular clarity and put into action by KEYS [41]. It is hard to believe that the striking gradients for arteriosclerotic heart disease mortality are largely due to differing fashions in death certification. Existing data have been well summarized in several publications [13, 42, 43].

As a general rule, the rates are greater in countries with higher living standards. Yet, several countries with high socio-economic status and advanced levels of medical care differ strikingly in arteriosclerotic heart disease mortality. Thus, the United States, Canada and Australia have much higher rates than the Netherlands, Sweden or Switzerland. It is entirely possible that differences in mortality in such situations merely indicate that the disease is as frequent but less lethal in such countries. More will be learned from refined studies among sub-groups than from national averages. Data on mortality serve a useful purpose by pinpointing areas in which field studies among living populations may advantageously be done.

Has coronary heart disease become more frequent in other countries, as appears to be the case in the United States? Such trends have been carefully analyzed for the British Isles and the consensus seems to be that the increase is largely real $[44,45]$. An interesting dissent is based on calculations intended to show that this increase can be accounted for by the survival of persons who would have otherwise died earlier in life from other diseases, especially infections [46, 47]. It would be true that persons prone to, say, tuberculosis would also be preferentially prone to coronary heart disease. It is not impossible that such general rather than specific proneness to disease exists; thus, States of the Union which have higher rates for arteriosclerotic heart disease have also, in general, higher rates for other causes [34]. For the time being, such speculations must remain interesting hypotheses.

In countries other than the United States, regional differences in mortality within the same country have also been reported. Mortality is higher in Eastern than Western Finland [48]. Similarly, rates are higher in some parts of the Irish Republic than in others [49]. These differences, as in Finland, may be partly due to diet [48]. Hardness of water has also been correlated with regional differences and will be discussed later. 


\section{EPIDEMIOLOGICAL PATHOLOGY}

Clinical methods are notoriously insensitive in detecting the early stages of coronary heart disease and even the advanced stages are frequently unaccompanied by symptoms or electrocardiographic signs. These shortcomings put limitations on the inferences which can be drawn from epidemiological data based on clinical evidence. Examination of pathological specimens, on the other hand, yields a quantitative spectrum of the lesions in both the coronary arteries and the myocardium by stages of severity. Not all the technical problems of quantitation, either in terms of gross or microscopic appearance or injection techniques, have been overcome and the problems in inter- and intra-observer variation remain troublesome; nevertheless, considerable progress has been made toward refining and standardizing the methods of pathological assessment $[50,51]$. As a result, epidemiological information based on pathological studies is becoming increasingly valuable. Such data are subject to the bias inherent in autopsy material; yet, this type of knowledge cannot be obtained in any other way. As long as the potential methodological and statistical pitfalls are kept in mind, epidemiological pathology will make an increasingly important contribution to the field.

\section{United States}

From the paramount point of view of prevention, it is critical to know to what extent coronary atherosclerosis exists among young persons. These lesions, except in the more advanced stages, may be partially reversible or, at least, subject to arrest [52] but the nature of the process is such that eventual disease control must aim at preventing significant lesions from developing. The problem was brought into focus by a report on young United States soldiers killed in action; 15.3 per cent of these men evidenced plaques in the coronary arteries occluding half or more of the lumen [53]. Similarly, in a study in New Orleans, the prevalence of coronary fibrous plaques was 17 per cent and 45 per cent in white males aged 10-19 and 20-29 years, respectively; the prevalence among females and Negroes of either sex was considerably lower at these ages [54]. In terms of surface involvement by fibrous plaques in the anterior left descending branch of the coronary artery, the area covered was 6.8 per cent in the 20-29 year old group and 22.2 per cent in the 30-39 year old group among white males in New Orleans [55]; since these lesions are focal by nature an area involvement of this degree is, indeed, extensive.

Several large-scale autopsy studies providing information on coronary and myocardial disease have been published in the United States [56-60]. In one series, representing a very high necropsy rate among all deaths in a community of 30,000 , 25-100 per cent atherosclerotic obstruction was noted in 74 per cent of autopsies on adults [60]. In any case, no one doubts the seriousness and extent of the problem in the United States. The need is for studies which will cast light on the factors which are responsible for this situation. Such studies include those in which an attempt is made to relate long-term living habits and events immediately preceding death to autopsy findings; some of these are in progress [24].

\section{Other countries}

Extensive investigations, comparing autopsy material from different countries by standardized methods, are in progress on the American continent [61]; preliminary data suggest the existence of marked differences [55]. Other groups are comparing the 
geographic pathology of coronary and aortic lesions in the United States and Africa, collecting simultaneous information on the fat content of tissues $[62,63]$. There is a suggestion that the extent of coronary disease may vary quite strikingly even though aortic involvement shows little difference $[64,65]$. The World Health Organization is taking an active lead in these international endeavors [66].

These studies aim largely at the demonstration and elucidation of overall differences between populations varying in overall living standards; of equal importance are those which compare groups within the same country. Where marked social gradients within the same population exist, similar gradients in the extent of atherosclerosis should be looked for; this has been done but representative autopsy material by social class is clearly difficult to obtain, particularly in countries of special interest for this purpose [67-70]. Some investigators have stressed the ubiquitous nature of atherosclerosis which would, by implication, belittle the importance of any such differences [71]. Confirmation of these views must await the use of truly comparable methods of assessment of lesions; it is entirely possible that, in some populations, social class gradients in themselves do not mirror the frequency of coronary atherosclerosis. The problem does not revolve around the question whether lesions are present or absent since, in this sense, atherosclerosis is indeed ubiquitous, but on whether their distribution differs in degree from population to population.

British studies are of particular interest and have been stimulated no doubt in part by a distinct tendency among workers in that country to attribute the arterial lesion predominantly to a defect in blood clotting mechanisms or to the related view that the epidemiology of the acute and supposedly thrombotic event may differ from the epidemiology of the slowly developing, underlying lesion [74]. A detailed discussion of this issue is beyond the scope of this review but it is worth stating, without further comment, that it is the exception rather than the rule for men who died of acute heart attacks to show evidence of recent thrombosis [57, 75]. Even in the series of CRAWFORD and his colleagues who adhere to the thrombotic theory, only half of these cases showed a recent thrombus; it must be admitted that this does not negate the theory which implies that even the non-occluding lesion is basically thrombotic [76]. Mitchell and Schwartz find that very recent infarcts invariably show thrombotic occlusion [77]. The field is in great need of further study by methods which can be applied to living populations as part of epidemiological surveys.

British data have suggested an inverse relation between myocardial scars (but not coronary atherosclerosis) and physical activity, pointing toward the importance of the collateral circulation and the need to investigate the myocardial as well as the arterial components of the heart [78]. Coronary atherosclerosis, as seen by the pathologist, appears to occur as commonly among British as among American young men [79].

\section{PREVALENCE AND INCIDENCE}

Knowledge of the frequency of coronary heart disease in different populations and population segments must necessarily be based on surveys among living people. In view of the fact that such surveys are generally difficult and costly in effort and funds, it is all the more remarkable how many such studies are now in progress. The aim is two-fold: to determine the presence of disease and to measure the predisposing and associated factors in the population under study. Knowledge of either of these two 
sets of data is important but clues on causation can only come from obtaining both simultaneously in the same persons.

Methods to determine the frequency of disease, and particularly the earliest signs of disease, are still inadequate. Nevertheless, the limit of usefulness in epidemiological studies of the time-honored clinical indices of angina pectoris, myocardial infarction and electrocardiographic changes has by no means been reached. The use of mutually acceptable, minimal criteria for categorizing the data and comparable methods for their collection should aid materially in establishing and interpreting meaningful trends and differences between people and groups. Much effort has been spent toward these ends $[5,9,80-84]$. At the same time, the use of more rational and sensitive electrocardiographic lead systems and such aids as roentgenographic visualization of coronary calcifications by newer techniques or estimation of myocardial contractility could contribute materially in defining the borderlands between health and disease [85-91].

Methods to assess risk are also in need of refinement. Progress has been made in standardizing lipid determinations and blood pressure measurements [92-94]. Methods of dietary evaluation and the quantitation of physical activity represent other epidemiological tools which require elaboration $[5,95,96]$. Biochemical, serological and physiological methods applicable in field studies will, no doubt, yield data on risk factors not hitherto identified. The study of reaction to emotional stimuli is an area to which increasing attention is being given [97].

With the advent of electronic computers, the whole field of data analysis has been simplified in many ways. Statistical computations which would have been out of practical reach can now be done with relative ease and speed $[98,99]$.

The recording of physiological data, such as electrocardiograms, on tape, not only reduces observer error and variation but saves much time [100, 101].

In epidemiological studies where very large numbers of data have to be analyzed and correlated, the availability of these procedures opens up new possibilities. It is a mistake to think that these developments will replace human thought and ingenuity; on the contrary, they demand especially high levels of these qualities.

\section{United States}

Prevalence rates are less telling than incidence rates because they necessarily apply only to survivors and because they are more sensitive to selective factors in the definition of the study population than a cohort identified for prospective studies of new disease incidence. However, prevalence studies are easier, covering as they do a shorter space of time, and yield valuable data as long as their limitations are kept in mind. Prevalence rates for coronary heart disease in men, based on several studies in the United States, are summarized in Fig. 1a; references arc given in the legend [102-110]. Prevalence rises with age, as expected, but striking differences from study to study are seen within each decade. Some of these differences are likely to be real but others are probably due, at least in part, to differences in diagnostic definition. The need for comparable methods and criteria in these investigations is well illustrated by these data. As a rough approximation, prevalence rates in the fifth decade (age $40-50$ ) are around $2-3$ per cent, rising to about 4-5 per cent in the sixth decade. The relatively high rates shown for the Tecumseh study are shown purposely since they are 


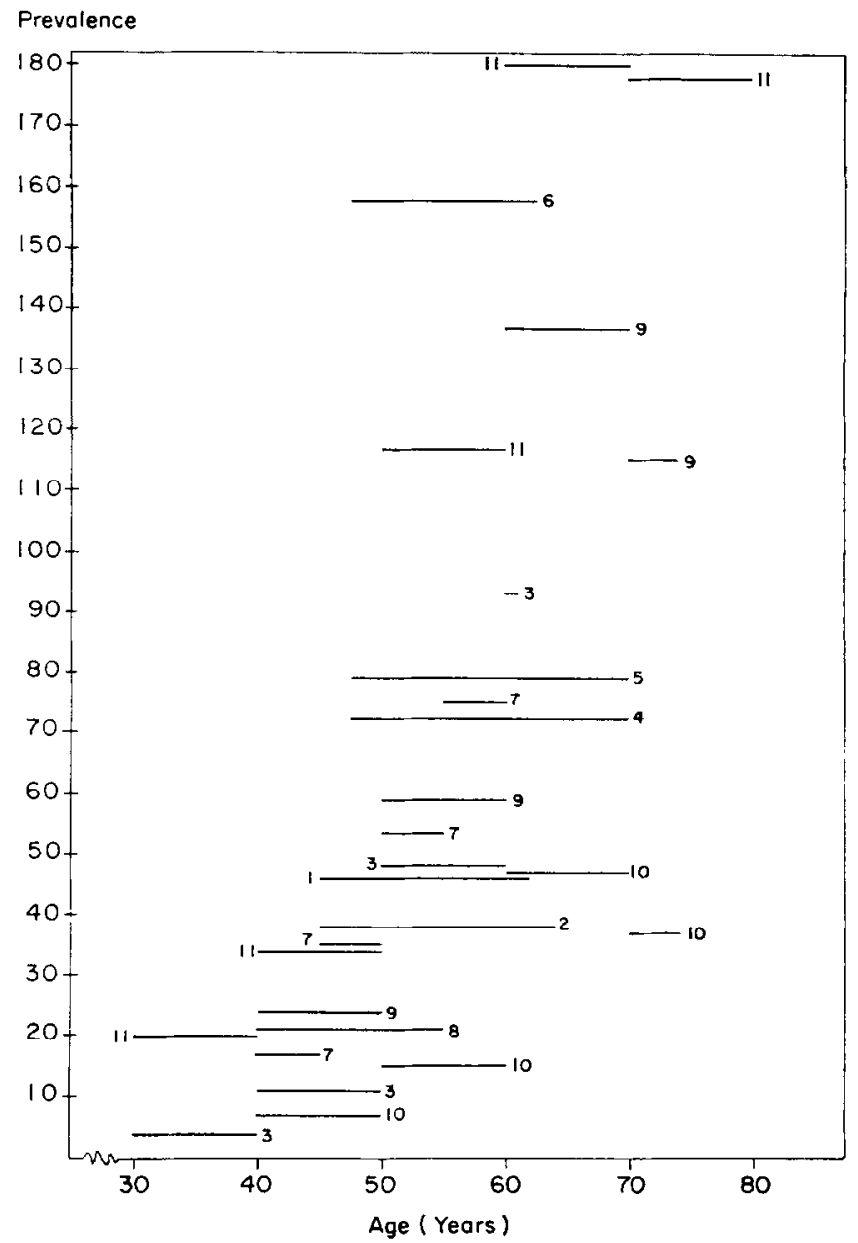

FIG. 1a. Prevalence rates for coronary heart disease among men (per 1000)

1. Framingham, Mass. [102]

2. Albany, N.Y. [103]

3. I os Angeles [104]

4. Pittsburgh [105]

5. New York (Italian) [106]

6. New York (Jewish) [106]

7. Chicago (StamLer) [107]

8. Chicago (PAUL) [108]

9. Evans Co., Ga. (White) [109]

10. Evans Co., Ga. (Negro) [109]

11. Tecumseh, Michigan [110] 
based deliberately on the inclusion of men who show frank inversion of T-waves over the left chest and corresponding limb leads in the absence of left ventricular hypertrophy [110]. While such T-wave changes do not signify, unlike abnormal Q-waves, past evidence of myocardial infarction, it is likely that they are indicative, at least in a country like the United States, of coronary heart disease in the vast majority of instances, after exlcuding other forms of heart disease which was done in this case. It is likely that the use of stricter criteria underestimates the prevalence of detectable disease in such a population though more rigid criteria have the advantage of affording a greater degree of certainty. Several studies have shown that the prognostic significance of so-called non-specific $\mathrm{T}$ and $\mathrm{S}-\mathrm{T}$ wave changes indicates a preferential risk toward the development of overt myocardial infarction [111-113].

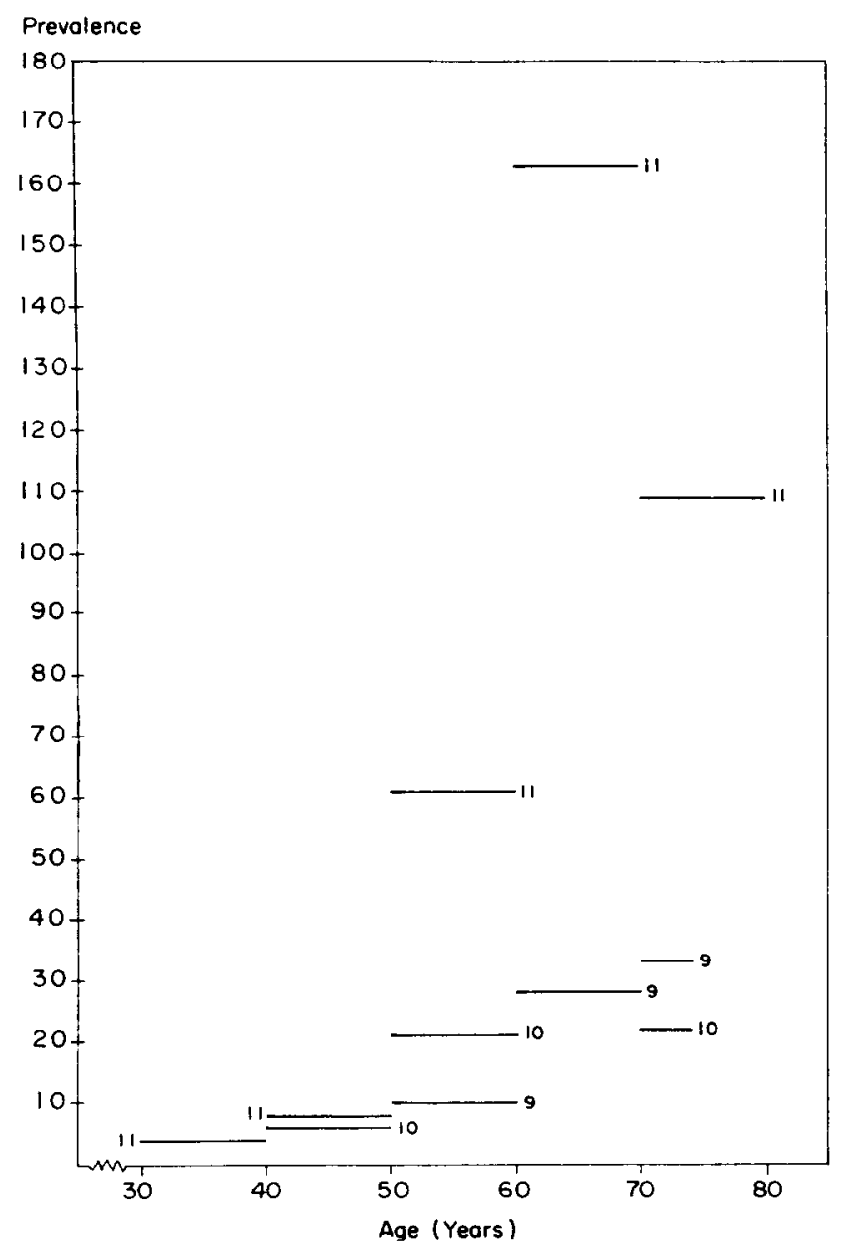

FIG. 1b. Prevalence rates for coronary heart disease among women (per 1000)

9. Evans Co., Ga. (White) [109]

10. Evans Co., Ga. (Negro) [109]

11. Tecumseh, Michigan [110] 
It is beyond the scope of this review to discuss these data in detail but close scrutiny reveals interesting similarities and differences, as does a comparison of the rates in men and women (Fig. 1b). No attempt had hitherto been made to present available data on prevalence in this fashion and the summary, as given, is of value in estimating the burden of this disease in the population and in the design of new epidemiological studies in different population segments. A comprehensive account of the prevalence of coronary and other forms of heart disease, based on clinical examinations in a random sample of the population of the United States was recently published as part of the National Health Survey [114]; the reported rates for coronary heart disease are generally within the range shown in Fig. 1.

Other data on prevalence are available, but are less readily summarized because of differences in sampling, study design or methods [115-117]. These and others have been reviewed [118, 119]. Other data are bascd on surveys using questionnaires without physical examinations [120]; such information is important for the delineation of medical care problems relating to coronary disease but does not lend itself easily to epidemiological inferences on etiology. Correlations between information of this type and data based on clinical examinations have been made [121, 122].

Prevalence studies among special population groups within the United States have been of considerable interest. Low rates as found among the Navajo Indians, the low rates as inferred from mortality data among Seventh-Day Adventists and the lower rates among Italian as compared with Jewish clothing workers in New York are cited $[106,123,124]$. Studies, to be extended longitudinally among monks belonging to different orders, will also aid in identifying the factors which account for these differentials [125].

Incidence rates from several studies are summarized in Figs. $2 a$ and $2 b$; references are given in the legend [103, 104, 107, 108, 126-132]. Considerable variations may again be noted among different investigations at given age ranges. In middle age, an average estimate suggests a yearly incidence rate of approximately 1 per cent among men and, perhaps, 0.2 per cent among women in the United States. Earlier remarks with regard to diagnostic criteria and methods apply here with equal force. Moreover, even though most of these rates are based on observations among adequate numbers of men and women, the standard error of each rate is considerable and some apparent differences may not be statistically significant, as has been pointed out [133].

\section{International comparisons}

Even though a considerable number of prevalence surveys have been conducted in recent years in various parts of the world, differences in population sampling and methodology make it difficult to compare these rates. Thus, the likelihood that marked geographic variations exist still rests largely on mortality statistics. Data based on the proportion of cases of myocardial infarction among hospital patients are difficult to interpret from an epidemiological point of view, though they do provide suggestive leads.

Two Brilish surveys have yielded very high prevalence rates (24-38 per cent)among men aged 55-64 years $[134,135]$. The prevalence was also high in a group of old men in Ireland [136]; the prevalence of definite coronary disease among these men, who were $65-85$ years old, was 20 per cent while men in their 60 's ,in a study in Birmingham, showed a rate of 8.4 per cent [137]. Among men and women mostly in their 70's, 


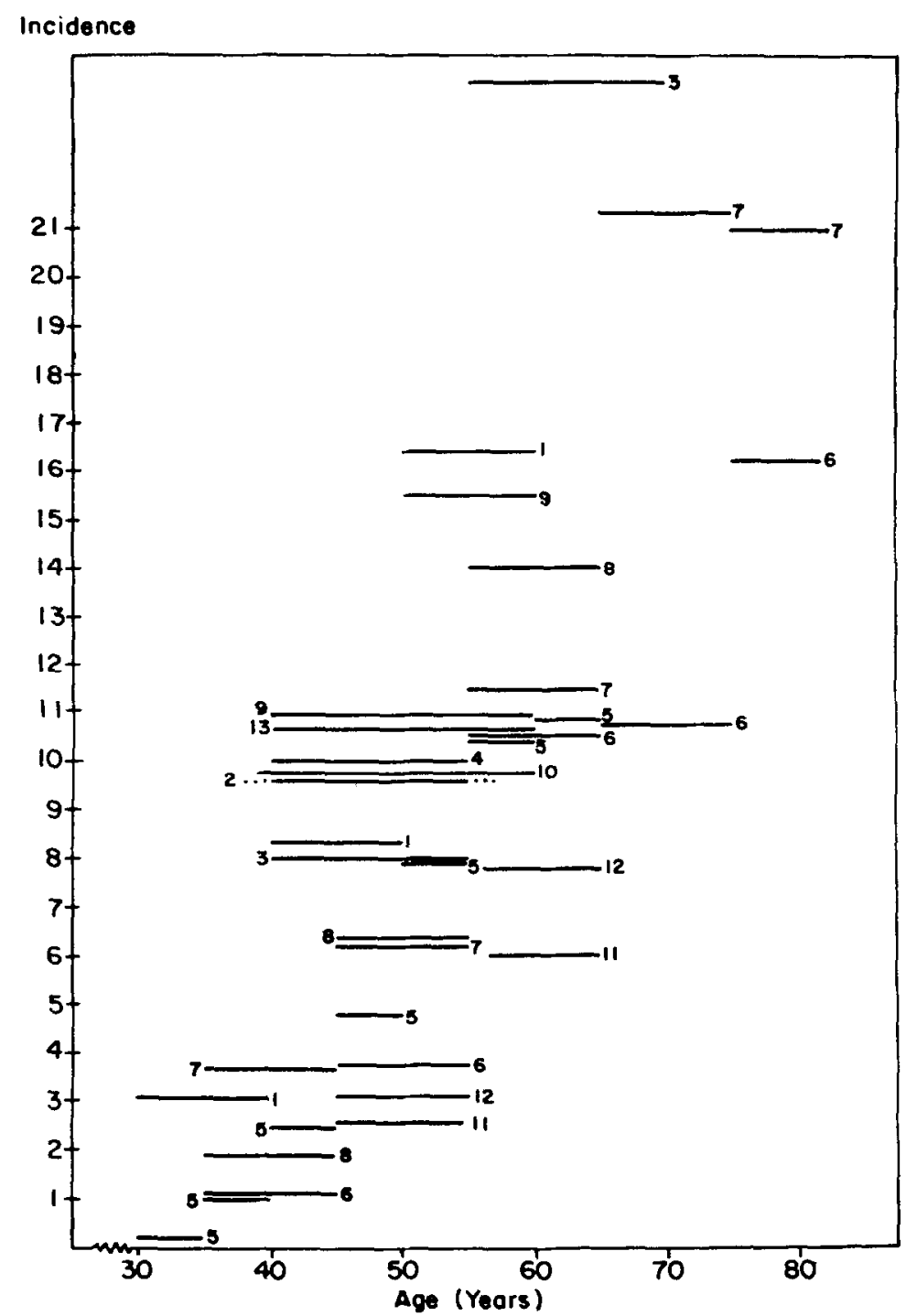

FIG. 2a. Incidence rates for coronary heart disease among men (per 1000 per year)

1. Framingham, Mass. [126]

2. Albany, N.Y. [103]

3. Los Angeles [104]

4. Chicago (PAUL) [108]

5. Dupont employees [127]-acute myocardial infarction only.

6. N. Dakota (Farmers) [128]

7. N. Dakota (Others) [128]

8. Middlesex Co., Conn. [129]

9. Chicago (STAMLER) [107]

10. San Francisco [130]

11. London (Conductors) [131]

12. London (Drivers) [131]

13. Zutphen, Netherlands [132] 


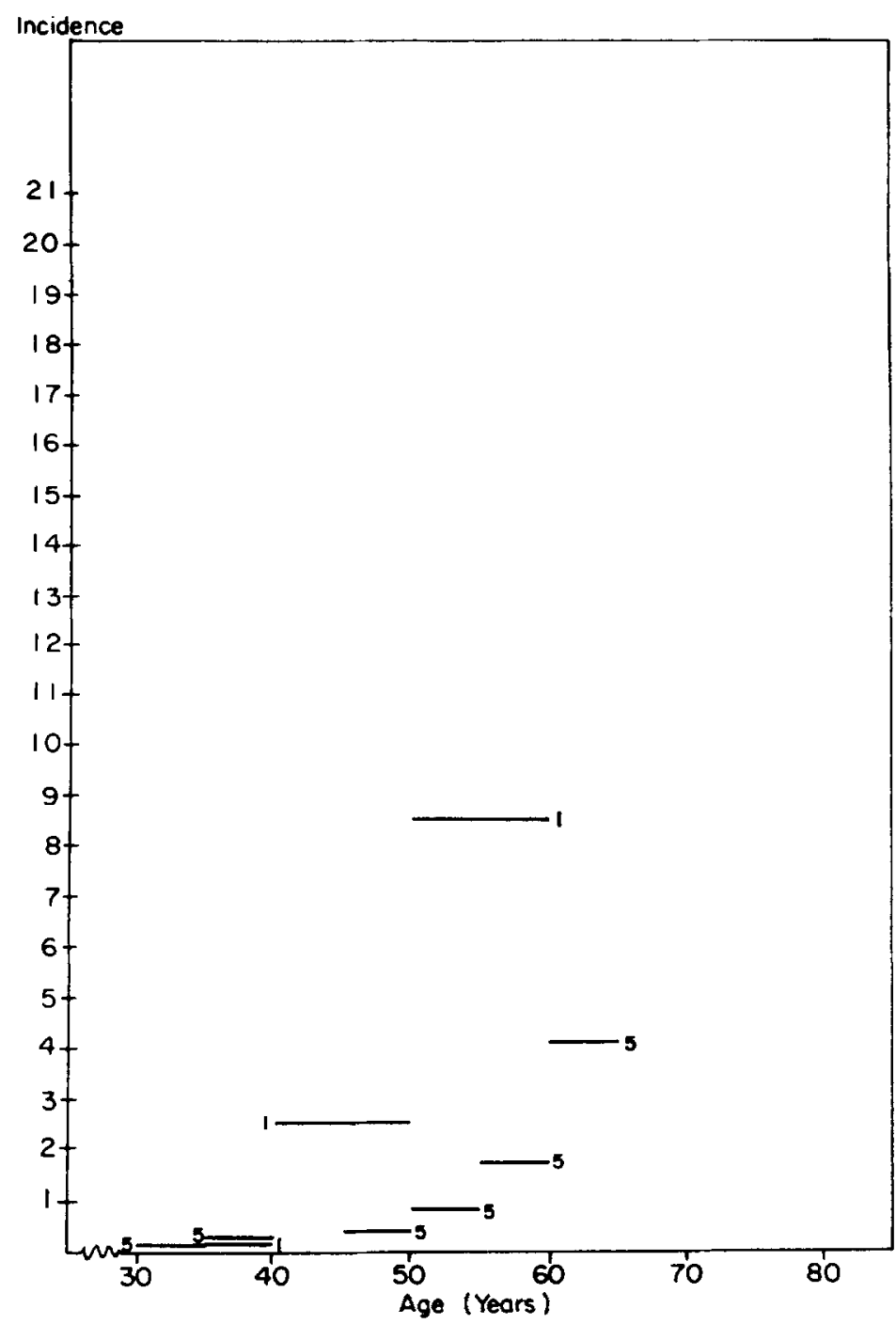

FIG, 2b. Incidence rates for coronary heart disease among women (per 1000 per year)

1. Framingham, Mass. [126]

5. DuPont employees [127]-acute myocardial infarction only,

angina was present among 6.5 per cent [138]. In a study of telephone workers in Britain and the United States, using identical methods, angina was of similar frequency but myocardial infarction was less common in Britain [139]. It is clearly not possible, at this time, to give a definitive estimatc of coronary disease prevalence in different groups in Britain. The rates certainly do not appear to be markedly lower than in the United States. Thus, in a representative sample of post office van drivers in Britain, deep and wide Q-waves alone were seen in the electrocardiograms of about 2-3 per cent of men aged 40-64 years [140]. 
Using comparable electrocardiographic criteria according to the 'Minnesota Code' [80], the latter rate, as found in Britain, may be contrasted with a rate of 1 per cent among Finnish men, aged 20-59 years [141]. In view of the high sensitivity of these rates to age, no fine comparison is possible at this point. The overall prevalence rate among Finnish men in their 40's and 50's was 5.9 per cent and 9 per cent, respectively, quite comparable with the rate in the United States where mortality is similar to Finland, whereas mortality from arteriosclertoic heart disease in Britain is appreciably lower than in either of these other two countries.

Several prevalence studies are in progress in other European countries, such as Switzerland [142], Czechoslovakia [143] and those which are part of the co-operative group under the chairmanship of KeYs [144] in Italy, Greece, Finland, Yugoslavia, the Netherlands, as well as in the United States; incidence rates will also be obtained in these surveys. Existing data on the incidence of coronary heart disease in Europe are scanty. The rates obtained by MoRRIS and his colleagues [131] among London Transport Workers are shown in Fig. 2a; these rates are not out of line with those in the United States. Similarly, preliminary data from a town in Holland [132] suggest similar rates in this community and Framingham, Massachusetts. It is possible, therefore, that mortality does not mirror morbidity and that men with coronary disease in Britain and the Netherlands are less likely to die early from the disease; further data are clearly needed. Incidence rates in Malmö, Sweden, are likewise similar to rates in the United States $[145,146]$.

Epidemiological data relating to coronary heart disease and factors predisposing to it from different parts of the world are so abundant that it would be impossible to summarize them adequately except in a lengthy review devoted to this subject alone. It is, perhaps, surprising that no such comprehensive review has been written though several authors have provided partial outlines [14, 15, 147-149]; the complexity of the field is evident. However, the data accumulation and methodological improvements are so rapid that a major review effort would be unrewarding since it becomes so quickly outdated. Populations in which important data have been collected are among white, Bantu and other racial groups [150-161] in Africa, the various ethnic subdivisions in Israel [162-169], groups in India [170-178], Japan [179-183], China [184, 185], the Pacific area [186-192] and in South and Central America [193-197]. It seems fair to conclude from these studies that, in general, the frequency of coronary heart disease is greater among the groups with higher socio-economic standards, though there may be epidemiologically important exceptions to this rule which demand further study [70]. This conclusion has little meaning in itself unless the factors related to these gradients can be identified. Those which are most obviously under suspicion are diet, serum cholesterol levels, physical activity and smoking; blood pressure distributions in some of these low-risk groups are not infrequently similar to those in Western countries [198] so that high blood pressure level in itself is not likely to be among the most critical factors underlying the majority of these populations differences. These risk factors will be discussed shortly.

Differences within Japan, comparing rates which seem to be lower in Nagasaki than Hiroshima [199], are likewise intriguing, as is the observation of lower rates in Hiroshima as compared with Framingham, Massachusetts [200]. Preliminary data suggesting that some manifestations of coronary disease in two populations of low [197] or relatively low [194] socio-economic status in Jamaica and Chile, respectively, may be 
similar to the rates in the United States is very challenging. Particular attention should be paid to data on predisposing factors among young people in these populations since data from Guatemala suggest that serum cholesterol levels show a social class gradient early in life [201]. Further knowledge is likely to come from intensive studies in well-defined groups rather than from broad and more superficial surveys; examples are the studies among the Maoris who seem to be especially predisposed and the Yemenite Jews who are also in rapid transition from a more primitive to a more 'Westernized' mode of life. Prospective data from such investigations are awaited with much anticipation. Epidemiological and dietary studies among populations who show little atherosclerosis have been recently reviewed [202].

\section{RISK FACTORS}

An attribute which appears to occur more commonly among persons with coronary heart disease than control subjects is defined, for the purpose of this discussion, as a 'risk factor.' It is implied in this particular definition that an association between the disease and a risk factor is not necessarily causal; proof of causality in epidemiological research is a complicated subject [203]. Strictly speaking, one should only use the term 'risk factor' if such proof has been obtained but a less rigorous definition serves the current needs, remembering that there are different levels of certainty as regards 'proof.' From the public health point of view, the question is how much certainty is required before action is taken. It is fair to say that much has been learned regarding risk factors in coronary heart disease, if 'risk factor' is defined as stated.

\section{Serum cholesterol and blood pressure levels}

Most workers in the field would probably agree that, among all the risk factors studied, the relationship between serum cholesterol and blood pressure levels and coronary heart disease is established most securely. Of the two, the relationship to serum cholesterol levels is somewhat more controversial. However, an association between coronary disease and serum cholesterol levels has been demonstrated in most epidemiological studies. These associations are less apparent in some studies than in others, such as those among a random sample of men in Wales [83] and those among clothing workers of Jewish origin in New York City [204]. In these two studies, an association between serum cholesterol levels, though slight, is nevertheless present. It is entirely conceivable that, in some groups, factors other than those related to the determinants of serum cholesterol levels are likely to be more dominant than in others. The evidence linking serum cholesterol levels and atherosclerosis is not, of course, based on epidemiological data alone but is in keeping with clinical and experimental observations. Moreover, it is supported by circumstantial evidence from epidemiological studies in various countries since mortality and, as far as it has been adequately measured, morbidity from coronary disease tend to be related to the 'average' serum cholesterol level in these populations [205, 206]. In countries with a lower disease frequency, patients with coronary disease tend to have higher levels than the population average [207] and appear to develop the disease generally at lower serum cholesterol levels than would be the case in, say, the United States; it must be remembered that myocardial infarction does, indeed, occur among persons with relatively low cholesterol levels in the United States though less frequently than at higher levels. 


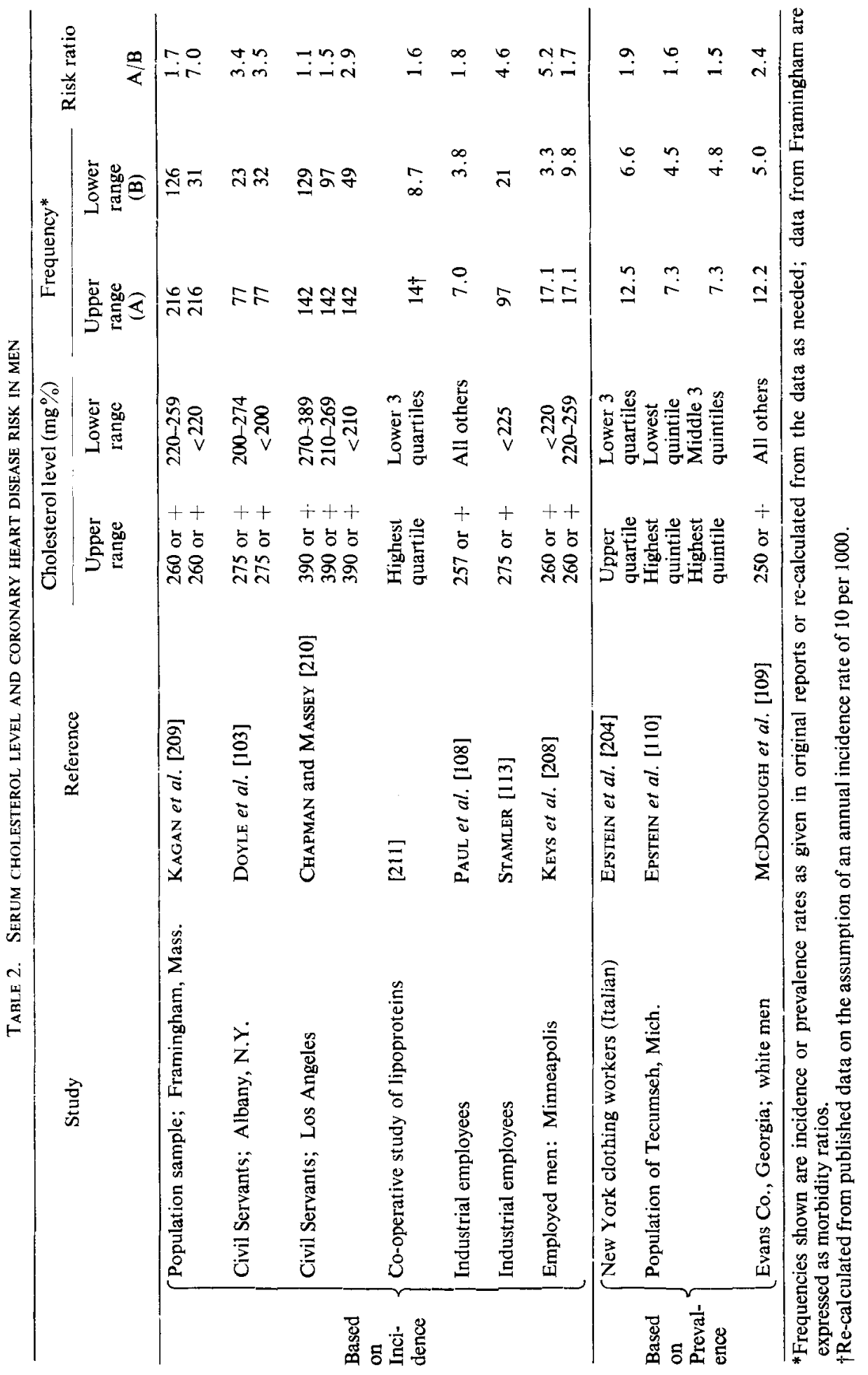




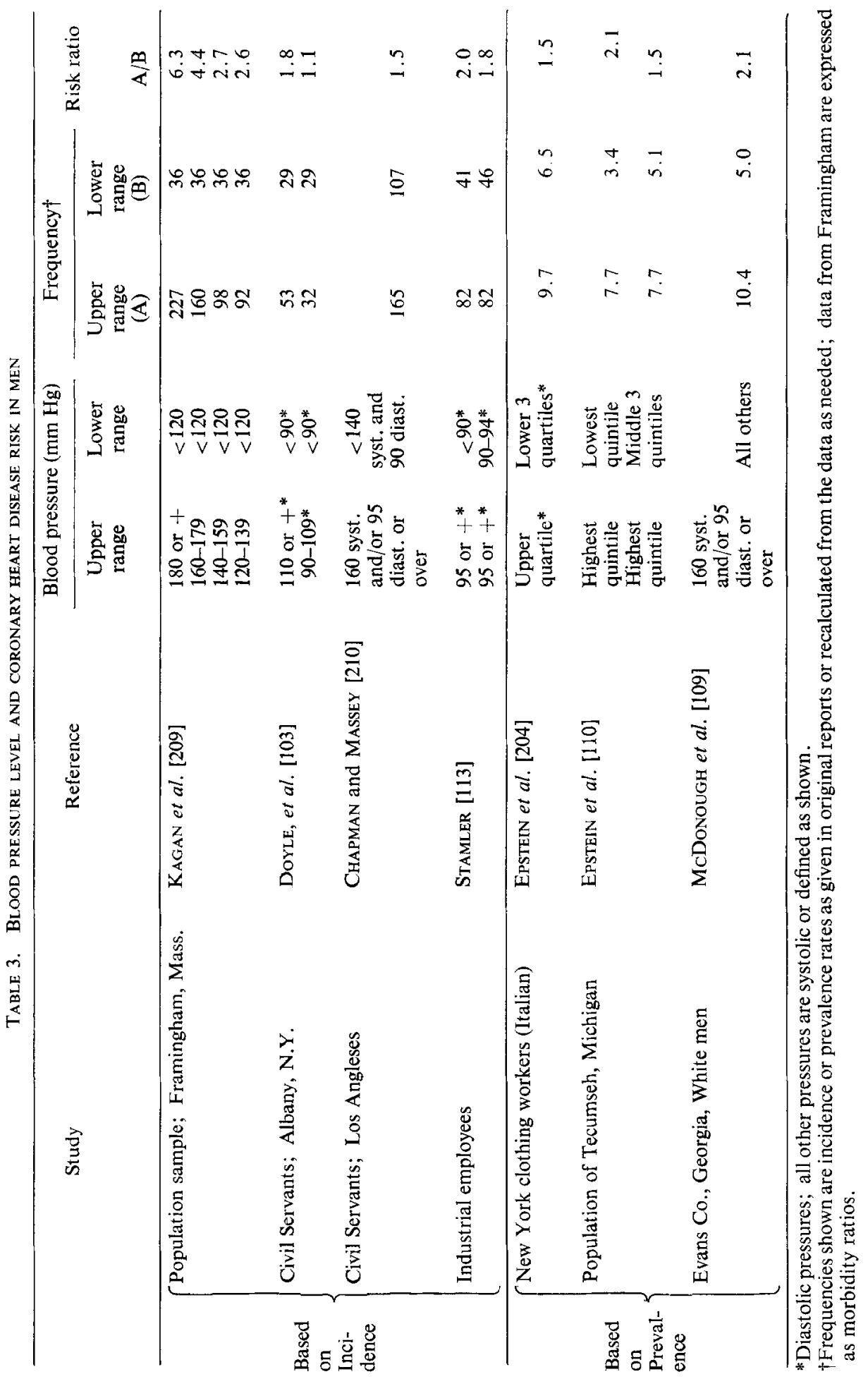


Keys and BlackBURN [22, 208] believe that there is an exponential relationship between cholesterol level and coronary disease.

The most valid data are those which are based on one-time or, preferably, prospective studies among representative population groups. Some of these are summarized in Table 2. It may, perhaps, come as a surprise that the number of studies which have yielded such data are still relatively few. Corresponding calculations for blood pressure are shown in Table 3 . The respective references are given in these tables [103, 108, 109, $110,113,208-211]$. The risk ratios are, of course, highly dependent on age and on the cutting points used. Space does not permit a detailed discussion but it would seem fair to generalize that the gradients are quite steep for both serum cholesterol and blood pressure when men in the uppermost and lowest parts of the population distribution are compared. Otherwise, however, the gradient tends to be about two-fold as a rough approximation, being less for prevalence data which may be subject to differential mortality and loss from the sample of sick persons.

In order to obtain a more striking differential, the combined risk from serum cholesterol and blood pressure elevation may be calculated. As an illustration, calculations based on unpublished data from the Framingham study, supplied through the courtesy of Dr. T. R. DAwBeR, may be presented (Table 4) . A risk ratio of 2.9 is obtained, comparing men high on one or both variables and those not high on either. This calculation also shows that two-thirds of the subsequent cases originate from

TABle 4. CoRonary heart diSEASE (CHD) IN MEN Aged 40-59, Based on 8-year follow-UP Data From Framingham STUdY*

\begin{tabular}{lccc}
\hline & $\begin{array}{c}\text { Cholesterol and/or } \\
\text { blood pressure in } \\
\text { upper ranget }\end{array}$ & $\begin{array}{c}\text { Cholesterol and } \\
\text { blood pressure in } \\
\text { lower range }\end{array}$ & Total \\
\hline $\begin{array}{l}\text { Number of men developing CHD } \\
\text { within 8 years }\end{array}$ & 66 & 32 & 98 \\
$\begin{array}{l}\text { Number of men not developing } \\
\text { CHD within 8 years }\end{array}$ & 354 & 548 & 902 \\
$\quad 420$ & 580 & 1000 \\
\hline Total & $16 \%$ & $5.5 \%$ & $9.8 \%$ \\
R-year incidence & & $16 / 5.5=2.9$ & \\
\hline
\end{tabular}

*Calculated from unpublished data supplied through the courtesy of Dr. T. R. DAwBER. Basic data have been converted to a denominator of 1000 men.

†Upper range for serum cholesterol $251 \mathrm{mg} \%$ or over; upper range for blood pressure 160 systolic or over and/or 95 diastolic or over. Lower range defined by values below these respective cutting points.

somewhat more than one-third (42 per cent) of the total group at risk. The predictive power of these two variables is clearly demonstrated. It is also shown that a very large proportion of middle-aged men are in the high risk group. The prevalence of these risk factors has also been shown to be high in other studies (Table 5). Depending on age and cutting point, roughly one-fifth of middle-aged American men have levels of one or the other of these two variables at which the risk toward developing manifest 


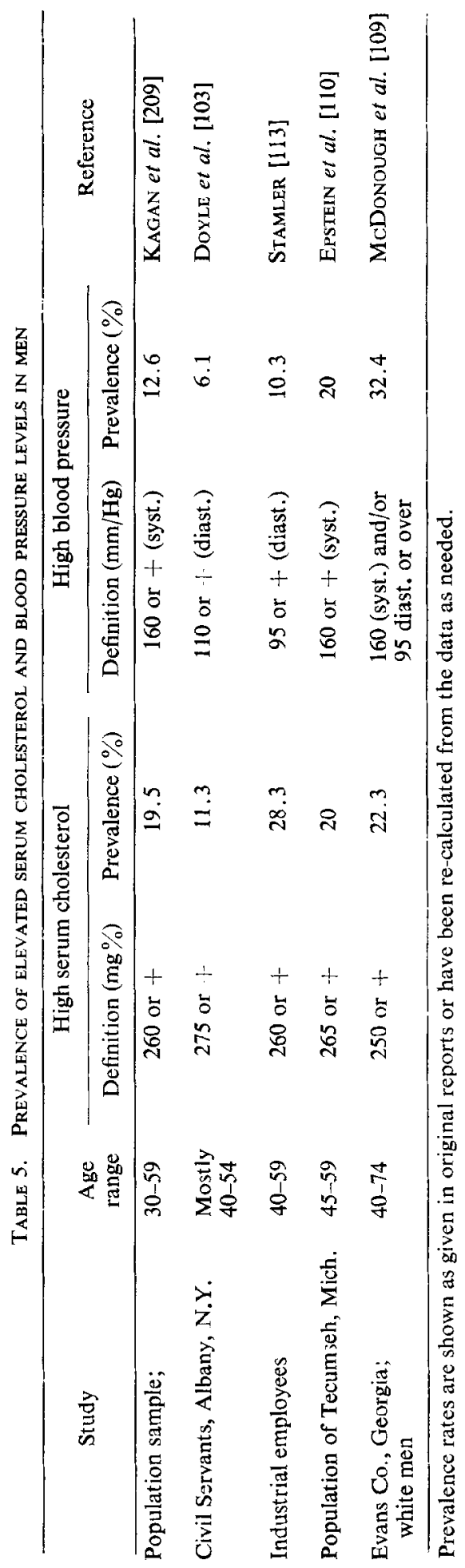


coronary heart disease is at least twice as high as the average risk. By using age-specific incidence rates from the Framingham study [126] for a life-table type of analysis, one can calculate that about 30 out of 100 American men will develop manifest coronary heart disease prior to the age of 65. By extrapolating from the data in Table 4 , it is likely that 20 of these 30 men will have high serum cholesterol or blood pressure levels. From the point of view of prevention, these figures speak for themselves. It may be added that there is no association [102], except at younger ages [110], between serum cholesterol and blood pressure levels so that the number of those who will be high on both can be calculated approximately from the respective prevalence rates of these two variables.

\section{Obesity}

In gencral, morbidity and mortality [212] are higher among the overweight than those whose weight is 'normal', using the term overweight rather than obesity advisedly because, in many cases, no allowance has been made for muscle mass or skeletal variation. It comes as a surprise, therefore, that some of the major epidemiological studies of coronary heart disease have not demonstrated a relationship between this condition and something less than gross obesity [102]. This is all the more unexpected since high blood pressure and obesity are correlated [102, 110] and, despite earlier evidence to the contrary, there is also a correlation between serum cholesterol levels and obesity [110]. It is quite probable that this paradox is explained in part by the fact that obesity is so common in the United States that a differentiating effect is lost; the effect might be more marked in other countries. Yet, it is true that there are countries in which obestiy is as common, but coronary disease less frequent, than in the United States [213].

In a disorder caused by multiple disturbances, the confounding effect of variables is so complex and the analysis of their separate contributions so dependent on large numbers of cases that it would be well to keep an open mind on the relationship between coronary disease and obesity. At this time there is little doubt that ohesity per $s e$ is a less potent risk factor than either serum cholesterol or blood pressure level so that control of obesity alone is not likely to make a major dent in the frequency of coronary disease.

Several investigations have demonstrated a relationship between body build'mesomorphy' - and both serum cholesterol levels and coronary heart disease [214]. This attribute must be considered, therefore, as a constitutional rather than environmentally determined risk factor and serves as an index of susceptibility among those in whom attention to environmental predisposing factors may be particularly important.

\section{Smoking}

A relationship between smoking and coronary heart disease has been suspected on clinical grounds for many years. Early data from epidemiological studies have failed to give definitive support to this suspicion [102]. More recently, however, much evidence has accumulated both from mortality data [215-219] and field studies $[108,113,128,220,221]$ which leaves no doubt that cigarette smoking and coronary disease are associated. There has been some hesitation to ascribed causal significance to this association since the mortality differential for coronary disease, as between 
smokers and non-smokers, is 1.5 - to 2 -fold, in contrast to the 10-or-more-fold gradient for lung cancer. This argument loses some force if it is recalled that the overall risk ratio for serum cholesterol and blood pressure is also of a similar order in a number of studies (Tables 2 and 3 ). The need for more data is great.

In the meantime, it is clear from the combined experience of the Framingham and Albany studies [221] that the risk ratio between smokers and non-smokers for myocardial infarction among men aged 40-49 years initially free from coronary disease and observed for 6-8 years is 3.5; for death from this disease, the ratio is as high as 6.0. The incidence rates from which these ratios were calculated had been adjusted for the independent effect of serum cholesterol and blood pressure. The risk ratio between smokers and non-smokers for angina pectoris showed no significant trend. Since there was a gradient according to the amount smoked, the influence for heavy smoking would have been even greater than indicated by these average ratios. Similarly, in STAMLER's experience [113], controlling for blood pressure, serum cholesterol and weight, the risk ratio between smokers and non-smokers, based on incidence, varied between 2.3 and 5.4 - a very appreciable gradient.

The report on "Smoking and Health" by the Surgeon General's Advisory Committee [222] summarized the data on mortality rates according to the amount smoked, from five major, prospective studies, including the one in Framingham. The rates vary by age and amount smoked; they are higher for young persons and in those smoking more. Among the relatively younger men smoking 20 cigarettes or more, the mortality ratio is generally well above two. In another part of the report, mortality ratios from several large prospective studies are given, based on 26,223 deaths from all causes; the pooled mortality ratio was 1.7 for coronary disease among cigarette smokers [222]. Persons who stop smoking have lower rates than those who continue [221, 222]. Pipe and cigar smoking seem to carry no excessive risk [222].

As in the case of other risk factors, inferences on causality cannot depend on the demonstration of association alone. A plausible mechanism must be advanced to relate physiological and biochemical consequences of smoking to the disease process. Space does not permit speculation on such mechanisms, If smoking contributes to the cause of coronary heart disease, the effect is probably not mediated by cholesterol or blood pressure since these variables are not consistently associated with smoking [223-225].

\section{Triglyceride and carbohydrate metabolism}

An association between serum triglyceride levels and coronary heart disease has been stressed lately. At the same time, except in a rare form of hyperlipemia, an increase in the proportion of carbohydrate at the expense of fat in the diet has been shown, somewhat paradoxically, to raise serum triglyceride levels [226, 227]. Not only diabetes but also diminished glucose tolerance in persons without frank diabetes, appears to be associated with coronary heart disease [110]. The intermediary metabolism of carbohydrate and fat are clearly interrelated at scveral points; in fact, the controversy over whether "fat burns in the flame of carbohydrates" took place many years ago while, conversely, every livestock breeder knows that carbohydrate can fatten animals. It is not yet known where cholesterol and phospholipids might tie into this picture although their esterification must certainly involve unsaturated fatty acid 
metabolism at some point [228]. Perhaps, the observation that chlorophenoxyisobutyrate (Atromid) lowers both serum cholesterol and triglyceride levels [229] will help in elucidating these metabolic pathways. In any case, the current interest in triglycerides has a rational basis and it would not seem illogical to view the problem in conjunction with aspects of carbohydrate metabolism. It would be tempting but still speculative to regard the common form of triglyceridemia as a manifestation of impaired glucose tolerance.

There are, at present, no published data on triglyceride levels from epidemiological studies if it is implied that, in such studies, cases and 'controls' must be derived from the same population. This is partly due to the fact that triglycerides must be determined in the fasting state which is not easy to accomplish in free-living populations. Current information, derived from studies in patients and controls, is at best, suggestive, while awaiting a more definitive approach based on epidemiological studics. According to the data from AlbRINK's group [230], 46 per cent of the men with coronary disease had elevated cholesterol levels, as compared with 26 per cent in the control group; however, 82 per cent of the patients but only 36 per cent of the controls had elevated triglyceride levels. Therefore, taking the data at face value, triglycerides seem to discriminate better but such calculations are very sensitive to age differences in frequency distributions and the choice of the cutting point. CARLSON [231] has found that triglycerides discriminate better than cholesterol between younger patients with coronary disease and controls, but the reverse effect was noted among older patients; this is perhaps, not surprising since his data show a decrease in triglycerides with age among patients whereas in both ALBRINK's and SCHAEFER's [232] studies, triglycerides normally increase with age. Similar findings on the relationship between coronary disease and serum triglycerides were reported by others [233, 234].

If triglyceride level should ever become established as one of the predictors of coronary heart disease, the frequency distribution in the general population would be important to know. As already mentioned, about a third of normal men in ALBRINK's series have elevated levels by her definition but, as far as can be extrapolated from the published data, only about 15 per cent of SCHAEFER's normal men and some 10 per cent of CARLSON's normals fell above $5.5 \mathrm{mEq} / 1$. (150 mg/100 ml or $2.0 \mathrm{~m}$-moles/1.). Part of this difference may be related to differences in method. New data will be awaited with interest. BRowN and his colleagues have studied triglyceride levels in healthy, young persons [235].

In general, the correlation between serum cholesterol and triglycerides is not high $[230,232]$, perhaps of the order of 0.6 . The relationship between weight gain and serum triglycerides has further bearing on these questions [236, 237], as does the findings of increased insulin antagonism in patients with myocardial infarction [238].

\section{Physical activity}

The thought that manual workers have less arteriosclerosis than sedentary individuals was expressed many years ago [40]. Better evidence for this impression was provided by MORRIS and his colleagues [239, 240] in their studies on London bus drivers and bus conductors, suggesting that myocardial infarction is about twice as common among the drivers although the incidence of angina tended to be in the reverse direction; drivers, however, were heavier in weight before they became engaged in this occupation. An extensive autopsy study by MORRIS and CRAWFORD has indicated that 
physical activity is less related to atherosclerosis than myocardial scars [78]; therefore, exercise may encourage a better collateral circulation rather than protect against atherosclerosis as such.

Following these provoking reports, the problem has been investigated by several other groups. Data based on mortality will be considered first. Recognizing that a number of studies in the United States have failed to demonstrate a social gradient in the frequency of coronary disease as discussed elsewhere [15], BREsLow and BUELL [241] re-examined mortality data in California, controlling for the 'general mortality risk', and demonstrated that sedentary workers showed a 40 per cent greater mortality from arteriosclerotic heart disease than heavy workers. Similarly, postal clerks have a mortality about 1.4 to 1.9 times as high as mail carriers in Washington, D.C. [242]. Among U.S. railroad workers, age-adjusted death rates from arteriosclerotic heart discase are 5.7 per 1000 for clerks, 3.9 for switchmen and 2.8 for section men [243]. With regard to field studies, the incidence of coronary heart disease was 1.7 times higher in non-farmers than farmers, as observed in North Dakota [128]. In the study in Evans County, Georgia, the overall prevalence of coronary heart disease did not differ among white farmers and non-farmers; however, there was a six-fold gradient in prevalence between farmers who did none of their own farm work as compared to those who did only farm work [109]; these differences were only partly explained in terms of serum cholesterol and blood pressure levels.

In summary, therefore, the evidence is in accordance with the hypothesis that physical activity and coronary heart disease are inversely related. This relationship has been demonstrated in groups which clearly differ in occupational activity; such groups are not easily found in an increasingly mechanized society. In view of the troublesome problem of pre-selection, ultimate proof that exercise protects against coronary disease requires a field trial in which participants are randomly assigned to exercise and non- exercise groups and observed over time; a study of this kind would obviously not be easy to conduct. Apart from the reports mentioned, the general topic has been reviewed and summarized $[224,245]$.

\section{Social and psychological influences}

Social and psychological factors interact to such a degree that it is impossible and, in fact, undesirable, to consider them separately. In the studies to be discussed, social indices are used in some and psychological measurements in others but the interpretation of the data must take both dimensions into account.

The social gradient for coronary disease in Britain [246, 247] is not generally found in the United States, as reviewed previously [15]. Nevertheless, urban-farm differences have already been mentioned and urbanization of rural areas is accompanied by a rise in arteriosclerotic heart disease mortality [248]. In a small rural community of ItalianAmericans, coronary disease mortality is strikingly low as compared with neighboring areas [249]. Men of urban background seem to have a higher incidence of coronary disease than men of rural background, regardless of their present residence [250]. Occupational and geographic mobility appear to be associated with a higher coronary disease incidence and men of European background generally tend to have a lower frequency of coronary disease than American-born men [250], with the possible exception of men from Ireland [251]. Religion has also been considered in these complex relationships [252]. 
The sex difference for coronary heart disease is usually ascribed to hormonal factors but the possibility exists that differences in the mode of life between men and women contribute to this phenomenon. The differences in mortality between married, widowed, single, and divorced women give some circumstantial support to this notion [253-256]. In another study, deaths from coronary disease were more common among married than single persons [257]. General physicians are said to be more prone to coronary disease than specialists [258].

The finding among the employees of the DuPont Company that executives have half the incidence of myocardial infarction than men in the lowest salary class is intensely interesting and cannot be explained in terms of differences in serum cholesterol, blood pressure, smoking or weight levels [259]. Of equal interest is the observation that executives who rose through the ranks have higher rates for coronary disease than those who did not [260].

Several investigators have noted differences in personality characteristics between men with and without coronary disease as reviewed elsewhere [15]; such associations are not necessarily causal, as has been pointed out [261]. There is a great need for good methods to assess personality and to measure 'stress'. The physiological and biochemical consequences of 'stress' may be more practical to measure than the provoking psychological factors [97].

Working long hours may be associated with excessive mortality from coronary disease [262]. In a retrospective study of mortality in younger men, no evidence was found for an excess of deaths among 'driving' individuals [263]; the problem of assessing such characteristics is clear. In a series of reports, ROSENMAN and FRIEDMAN have described a personality pattern which they consider characteristic of the coronaryprone individual and have found it associated with some known predisposing factors [264]; it is claimed that the personality pattern in question predicts coronary heart disease more effectively than serum lipid and blood pressure measurements [130]. These preliminary data await detailed analysis after a more extended period of observation. An increase of serum cholesterol levels under stressful circumstances has been shown in several [265-269] but not all [270] studies.

An attempt has been made to show that social and psychological influences may well play a role in the genesis of coronary heart disease but the relative importance of these influences as compared with others, their interactions and the effective pathways remain to be explored. Considerable work along these lines is underway; some more general discussions have been published [271-276].

\section{Genetic factors}

There is presumably no illness in which genetic predisposition plays no part and atherosclerosis and coronary heart disease are certainly no exceptions. Three predisposing factors in particular-serum cholesterol, blood pressure and blood sugar levels -are partly under genetic control so that familial aggregations of coronary heart disease can be anticipated to exist. Such aggregations are likely to have both genetic and environmental determinants since families share their environment as well as their genes. Hereditary factors in coronary heart disease have recently been reviewed in considerable detail [277] and a summary of data on genetics and ath erosclerosis has been given elsewhere [278]. 
For the purpose of this review on epidemiology, it must be stated that epidemiological studies as such have, so far, contributed little to this field although epidemiology is, in one sense, the study of the transactions between environmental and genetic factors. Familial data, based on the examination of relatives, have generally not been a part of epidemiological studies of coronary heart disease, in contrast to epidemiological studies of some of the predisposing factors. The methodological and logistic problems in such studies are very considerable [279] and account, in part, for the fact, that so few have been done. The epidemiological studies by THomas in Baltimore [280] and in Tecumseh, Michigan, have a strong focus on observations within families [281, 282]. Progress in this area will depend on further studies of coronary heart disease and predisposing factors in relatives of propositi and suitable control groups.

\section{Other risk factors}

It is unfortunate that, for reasons of space, this section must be short and lacking in detail since under this overall heading there will no doubt be hidden several hitherto unexplored or unknown risk factors. One reasons why extensive accounts of the influences discussed earlier could be given is that more research has been done in these particular areas. In other areas, epidemiological studies have been hampered by lack of methods sufficiently reliable and simple enough to be applied to field studies. This is particularly true in connection with the factors involved in thrombosis, blood coagulation and fibrinolysis [283]. What may matter with regard to these factors might not be their static levels, if such exist, but their dynamic changes which are difficult to ascertain in population studies; nevertheless onetime measurements of platelet adhesiveness would seem very worthwhile [284].

The influence of hormones on atherogenesis is of great epidemiological relevance. The sex differences in the frequency of coronary heart disease are certainly due, in large part, to hormonal factors. Inter-individual differences in lipid levels are probably determined partly by hormonal patterns, as are the fluctuations in level in the same person under various environmental stresses. Hormones have also been shown to affect the metabolism of the arterial wall. It is likely that a number of epidemiological phenomena relating to differences in disease frequency between various population groups arc mediated in some fashion by hormonal interactions. Gonadal, adrenal, thyroid and pituitary hormones have all been studied in relation to atherogenesis in experimental animals; methodological difficulties have limited the assessment of hormonal factors in man, particularly in epidemiological surveys. Several investigations have, however, suggested that hormonal therapy may influence the course of coronary heart disease in human beings. A number of reviews on these complex hormonal interrelationships in atherosclerosis are available [285-287]. Finally, differences in reproductive performance among women with and without coronary heart disease suggest not only that affected women have distinctive hormonal patterns but that these patterns may contribute to the genetic make-up of the population [288].

More generally, any factor involved in atherogenesis is of obvious relevance to the epidemiologist. It is an urgent task to bring these experimental and clinical leads and suggestions within the realm of epidemiological testing and, conversely, to test in the clinical and experimental setting some epidemiological observations. Among these, the interesting inverse relationship between water hardness and coronary heart disease mortality comes to mind $[289,290]$; a comprehensive analysis of other causes of 
mortality andiwater hardness [291] has revealed that such a relationship is not confined to coronary disease so that the problem of 'causation versus association' is raised once more.

Among clinical-epidemiological interrelationships, there is a need to assess the significance of so-called 'non-specific' electrocardiographic changes. It would appear that most of these, at least in Western countries, are associated with myocardial disease of atherosclerotic origin. Yet, the electrophysiology of these alterations which can also be evoked by functional disturbances [292], is still poorly understood. Several studies, as summarized by UNGERLEIDER [111], suggest that persons with such changes are more prone to develop frank coronary heart disease than those with 'normal' electrocardiograms. The fine analysis of the QRS complex in terms of the first derivative of the electrocardiogram also deserves epidemiological study because of its potential as a valuable predictor [293].

\section{Multiple risk factors}

If single risk factors have predictive value, as has been shown, simultaneous evaluation of multiple risk factors should enhance predictive power; this has already been discussed with regard to serum cholesterol and blood pressure levels. Data on combined risk, based on serum cholesterol levels, blood pressure levels, smoking and weight, have been reported by several groups at various meetings but are still largely unavailable. Such data have, however, been published from the Framingham study and are likely to be quite representative [126]. Taking cholesterol, blood pressure and smoking as risk factors, the morbidity ratio of 45 for myocardial infarction when none of the three factors are high, rises stepwise to 563 when all three are high; it is noteworthy that only 49 per cent of all the men aged 30-59 initially at risk were not high on all three factors while 51 per cent were high on one or more. On dividing cholesterol and blood pressure levels into three ranges and adding the presence or absence of left ventricular hypertrophy on the electrocardiogram, among men aged $40-49$ in Framingham, only 9 per cent of the population is 'low' on all three variables; the morbidity ratio of 16 for all forms of coronary disease among these men rises to no less than 261 among the 8 per cent of the men who are 'high' on two of these three factors. It is quite obvious that not all men in the United States are prone to coronary heart disease though they represent a regrettably small minority.

Other data from the Los Angeles study [210], to quote one example from this study, show that the incidence of coronary heart disease is 2.5 times higher when blood pressure and cholesterol are elevated than when both are in the lower range. Since there are interactions between the variables, some of these calculations are very difficult and discriminant function analysis has been applied to this problem [294]. Further data, based on prevalence, from the Evans County study [109] indicate that white men who rank 'high' on cholesterol, blood pressure and social class manifest coronary disease almost ten times as often as men who are 'low' on all three variables. Comparing men whose serum cholesterol and blood pressure are low with men high on both, weight and smoking held constant, STAMLER finds a 7- to 9-fold difference in incidence between these two groups; only 209 of the 1329 men (16 per cent) fell into the 'low' group [113]. Related data have been discussed by STAMLER elsewhere [295]. Further information on the predictive value of risk factors in combination comes from the study of PAUL and his colleagues, already mentioned [108], based on hitherto 
unpublished six-year follow-up data [296]. In that study among employed men, cigarette smoking and coffee intake were both independently related to the incidence of coronary heart disease as were serum cholesterol and blood pressure levels. On comparing incidence rates when serum cholesterol, cigarette smoking and coffee drinking were all 'high' with the rates when all three were 'low', an almost 5-fold difference was found; a similar gradient was observed when the analysis was repeated, substituting blood pressure for serum cholesterol. Incidence was 4.1 times greater when blood pressure, serum cholesterol and cigarette smoking were all 'high' as compared with all three being 'low'. Another three-way analysis, based so far on prevalence data, was done as part of the Tecumseh Community Health Study [281, 282], using as the variables, serum cholesterol, blood pressure and blood glucose levels, the latter being determined one hour after a standard load. When all three variables were in the upper range (i.e. above the age and sex-specific 80 th percentile point), the 'relative prevalence' was 5.5 times higher among men and 6.2 times higher among women, in comparison with the rates when all three variables were below the 80th percentile [297].

Such data dispel the notion that little is known about the precursors of clinical coronary heart disease. The predictive power of the combination of these multiple risk factors is clearly striking. At the same time, it is apparent that the prevalence of these factors singly and particularly in combination is so great that a major proportion of the population is at risk because of one or more of them. It is not possible, therefore, in terms of these particular variables, to identify a minority of 'susceptibles' among whom the majority of clinical events will occur. Perhaps, this is in the nature of the disease but, as likely, more discriminating risk factors remain to be identified.

\section{PREVENTION}

'Prevention' in relation to coronary heart disease must be taken to mean that premature onset of the disease should be prevented; death from a heart attack at an advanced age would not seem necessarily undesirable. The early toll from the disease has already been stressed. The need for prevention in the above sense is emphasized by the fact that the mortality from acute heart attacks is underestimated from hospital statistics since many victims never reach the hospital. In the Framingham experience [298] which takes account of this factor, 34 per cent of all the middlc-aged men who developed 'heart attacks' died within three weeks of the onset and 56 per cent of those who died survived their attack for less than one hour; the immediate risk of dying was highly related to initial serum cholesterol level but not, in this case, to high blood pressure. These figures highlight the need to prevent the attack from occurring in the first instance.

Since none of the risk factors discussed have been 'proven' to be causally related to coronary heart disease, only circumstantial reasoning would permit the inference that control of these risk factors would reduce disease incidence. The circumstantial evidence is, however, strong that reduction of blood pressure and serum cholesterol levels, avoidance of at least excessive smoking of cigarettes, maintenance of adequate physical activity and of reasonable weight would be effective preventive measures. Regarding control of these predisposing factors, all but the first are dependent to a greater or lesser degree on a decision, however hard it may to be make it, on the part of the individual. Elevated blood pressure cannot be controlled, as far as it is known today, by environmental means since the environmental determinants of blood pressure 
are inadequately known; the possible importance of salt intake in this connection has been discussed elsewhere [198]. Since some 20 per cent of middle-aged men in this country have frankly elevated blood pressures, it may at least be questioned whether as much as one-fifth of this population should use anti-hypertensive drugs prophylactically, considering that most drugs are necessarily 'toxic' to some extent; the problem is to balance the risk of toxicity against the risk of premature coronary heart disease, or, for that matter, strokes. There remains the problem of serum cholesterol levels to which the remainder of this discussion will be confined.

It may be calculated [299] that a reduction of serum cholesterol level of about 15 per cent among American middle-aged men, taking the competing effect of blood pressure into account, might lower the incidence of coronary heart disease by about 35 per cent. While this figure cannot be more than an intelligent guess on the basis of current data, the possibility of making a dent of this, admittedly not optimal, magnitude by intervening on one of the several risk factors alone must be considered most earnestly from a public health point of view. There is reason to think, if only circumstantially, that a lowering of serum cholesterol level, even without intervening on the blood pressure factor directly, might benefit those in whom blood pressure is raised. Data from the Framingham study indicate that the incidence of coronary heart disease among hypertensives is rather less than half as high when serum cholesterol level is, say, $200 \mathrm{mg} / 100 \mathrm{ml}$ than at levels of $250 \mathrm{mg} / 100 \mathrm{ml}$ [126].

It has been known for some years that serum cholesterol levels, under closely supervised conditions, can be lowered by reducing the amount of saturated fat in the diet [300-302]. Whether or not a simultaneous increase in the amount of polyunsaturated fatty acids will further enhance this effect is not entirely certain. In any case, moderate amounts of fat in the diet, supplied by partially substituting unsaturated for saturated fats, will make the diet more palatable for the average person in this country and will prevent a possible increase in serum triglycerides which may occur on a low fat diet and, for the reasons mentioned before, might be undesirable. With regard to the interrelations between carbohydrate and lipid metabolism discussed earlier, attention to weight control through avoidance of excessive carbohydrate intake might, in addition, have a favorable effect on the aspects of atherogenesis related to impaired glucose tolerance.

There is no good evidence that diets in which about 30 per cent of the calories come from fat, with about equal amounts being derived from saturated, mono-unsaturated and polyunsaturated fatty acids, might be atherogenic. It must be admitted that diets high in polyunsaturated fatty acids can cause arterial lesions in rats even though serum cholesterol is reduced [303]. Furthermore, the critical issue whether a fall in serum cholesterol with a diet high in polyunsaturated fats is accompanied by increased sterol excretion has not been settled. This matter has been studied in man by several investigators but no consensus has been reached. If sterol excretion remains constant in the face of a decrease in serum cholesterol while the diet is changed from one high in saturated fats to one high in polyunsaturated fats, as has been reported [304], it must be inferred that cholesterol shifts from the serum into the tissues under these circumstances.

Several studies involving prospective observations among volunteers, institutional groups and high-risk individuals on such modified fat diets are now underway [305-307]. Preliminary results from one of these groups suggest a strikingly low 
incidence of coronary heart disease among these volunteers [306]. In addition, a national pilot study on the feasibility of a definitive, active prophylactic trial concerning the effect of such diets on the incidence of coronary heart disease is in progress [308]. The experience gained in these several studies leaves no reasonable doubt that freeliving individuals will adhere to fat-modified meals and that an average serumcholesterol lowering of about 15 per cent of the control value (e.g. a reduction from an average of $235 \mathrm{mg} / 100 \mathrm{ml}$ to $200 \mathrm{mg} / 100 \mathrm{ml}$ ) can usually be achieved. The stage is, therefore, well set for a serious attempt toward dietary control of coronary heart disease as, at least, one measure which may aid in the prevention of this condition. Among the many publications on this subject, a number will serve to document further these summary remarks [309-312].

A series of investigations have suggested that serum cholesterol and dietary fat intake are not corrclated in Western countrics [108, 313-315]. This is hardly surprising since almost everyone in these countries is consuming a diet which is high in total and saturated fat. This is well illustrated in the study by PAUL and his associates who found no difference in coronary disease incidence among men in the highest and lowest quintile of fat intake [108]; however, even the men in the lowest quintile consumed 36 per cent of their calories as fat and their average serum cholesterol level was as high as 247 $\mathrm{mg} / 100 \mathrm{ml}$ so that, as the authors indicate, minor alterations in the so-called 'average' American diet are not likely to achieve the desired goal. At the same time, the experiences already quoted [305-308] do not suggest that these alterations must be so drastic as to be unacceptable.

\section{SUMMARY AND RECOMMENDATIONS}

The burden and trend of mortality from coronary heart disease in the United States and other countries have been defined on the basis of mortality statistics and pathological studies. Data on morbidity in terms of prevalence and incidence rates in different populations were reviewed and correlated with a series of associated risk factors. Possible means of preventing coronary heart disease were discussed. The cumulative evidence strongly suggests that environmental influences are largely responsible for making coronary heart disease a major public health problem in many countries.

In order to turn suggestive evidence into greater certainty, more research is required. While remarkable strides have been made in recent years, further progress depends not only on more studies but on methodological improvements. One prerequisite is the use of methods which will make it possible to be certain that the observed differences and similarities between population groups are real and to assess the relative contributions of risk factors which may account for these findings. Another prerequisite is the development of more valid, sensitive and reliable methods for disease detection and, particularly, detection of early, pre-clinical deviation from health. The same need applies to a more precise definition of known risk factors and the discovery of hitherto unrecognized risk factors, in order to detect susceptibility to coronary heart disease at younger ages.

For the study of susceptibility, more emphasis should be given to observations among younger persons and familial interrelationships in order to separate environmental factors from genetic predisposition. Such knowledge will make it eventually possible to institute preventive measures early in life among those most highly at risk. 
In the meantime, an attempt was made to show that epidemiological research in the past decade made significant inroads into the problem of predicting coronary heart disease and that some of these discoveries are ready to be put to the test in experimental coronary disease prevention programs.

Acknowledgements-This work was supported by a Public Health Strvice Research Career Program Award HE-K6-6748 from the National Heart Institute. Great appreciation is expressed to many workers in the field who have generously furnished reprints and manuscriots which have been of much help in writing this review.

\section{REFERENCES}

1. Langmuir, A. D.: Epidemiology; in 1st Proc. Nat. Conf. Cardiovascular Diseases, p. 182. American Heart Association, New York, 1950.

2. Dawber, T. R. and KanNel, W. B.: Susceptibility to coronary heart disease, Mod. Conc. cardiov. Dis. 30, 671, 1961.

3. Watt, J.: Arteriosclerosis and epidemiology. Presented at the 7th Annual Meeting of the American Society for the Study of Arteriosclerosis, Chicago, Illinois, September 1953 (Unpublished).

4. American Heart Association: Conference on Epidemiology of Atherosclerosis and Hypertension. Harriman, New York, 1956.

5. Pollack, H. and Krueger, D. E.: Epidemiology of cardiovascular diseases, methodology, hypertension and arteriosclerosis, Amer. J. publ. Hlth 50, (Suppl.) 10, 1960.

6. World Health Organization: Hypertension and coronary heart disease: Classification and criteria for epidemiological studies, Wld Hlth Org. techn. Rep. Ser. No. 168, 1959.

7. World Health Organization: Arterial hypertension and ischaemic heart disease: Preventive aspects, Wld Hlth Org. techn. Rep. Ser. No. 231, 1962.

8. Burgess, A. M., Fejfar, Z. and Kagan, A. R.: Arterial hypertension and ischaemic heart disease: Comparison in epidemiological studies, Chron. Wld Hlth Org. 16, 437, 1962.

9. Weinstein, B. J., Epstein, F. H.: The Working Subcommittee on Criteria and Methods, Committee on Epidemiological Studies, American Heart Association: Comparability of criteria and methods in cardiovascular disease epidemiology. Report of a survey, Circulation 30, 643, 1964.

10. Keys, A. and White, P. D.: Cardiovascular Epidemiology. Hoeber, New York, 1956.

11. MANN, G. V.: The epidemiology of coronary heart disease, Amer.J. Med. 23, 463, 1957.

12. REID, D. D.: The epidemiology of coronary disease, Practitioner 180, 184, 1958.

13. Bronte-Stewart, B.: The epidemiology of ischaemic heart disease, Postgrad. med. J. 35, 180, 1959.

14. Stamler, J.: The epidemiology of atherosclerotic coronary heart disease, Postgrad. med. J. 25, $610,685,1959$.

15. Epstein, F. H.: Epidemiology of coronary heart disease, in Modern Trends in Cardiology. Ed. by MORGAN JONES, A. Butterworths, London, 1960.

16. KaGan, A.: Atherosclerosis of the coronary arteries--epidemiological considerations, Proc. roy. Soc. Med. 53, 18, 1960.

17. MoRRIs, J. N.: Epidemiology and cardiovascular disease of middle age, I and II, Mod. Conc. cardiov. Dis. 29, 625, 1960; and 30, 633, 1961.

18. Morris, J. N.: Epidemiological aspects of ischaemic heart disease, Yale J. Biol. Med. 34, 359, 1961.

19. Bronte-Stewart, B. and Krut, L. H.: The interdependence of prospective and retrospective studies in research on ischaemic heart disease, J. Atheroscler. Res. 2, 317, 1962.

20. Stamler, J.: Cardiovascular disease in the United States, Amer.J. Cardiol. 10, 319, 1962.

21. Acheson, R. M.: The etiology of coronary heart disease, Yale J. Biol. Med. 35, 143, 1962.

22. Keys, A. and BlackBURN, H.: Background of the patient with coronary heart disease, Progr. cardiovasc. Dis. 6, 14, 1963.

23. Study Group on Development of Methods for Assessing Adequacy of Cardiovascular Diseases: Mortality Statistics for Epidemiological Studies. National Office of Vital Statistics, Public Health Service, Document No. 525, January 1961. 
24. Beadenkopf, W. G., Abrams, M., Daoud, A. and Marks, R. V.: An assessment of certain medical aspects of death certificate data for epidemiologic study of arteriosclerotic heart disease, J. chron. Dis. 16, 249, 1963.

25. Morryama, I. M., Dawber, T. R. and Kannel, W. B.: Evaluation of diagnostic information supporting medical certification of cardiovascular disease deaths. Presented at the 91st Meeting of the American Public Health Association, November, 1963.

26. Lew, E. A.: Some implications of mortality statistics relating to coronary artery disease, J. chron. Dis. 6, 192, 1957.

27. Morryama, I. M.: The change in mortality trend in the United States, Publ. Hith Serv. Publ. No. 1000, Ser. 3, No. 1. U.S. Dept. I Iealth, Education and Welfare, Washington, D.C., 1964.

28. SAMPSON, J. J.: The next ten years, Amer. Heart J. 14, 1, 1964.

29. U.S. Public Health Service: Calculated from U.S. Census Figures and Tables in Cardiovascular Disease (Publ. Hlth Serv. Publ. Nos. 429 and 1083), U.S. Govt. Printing Office, Washington, D.C., 1955 and 1963.

30. U.S. Public Health Service: Unpublished data of Krueger, D. E., National Heart Institute.

31. BORHANI, N. O. and HeChTER, H. H.: Recent changes in CVR disease mortality in California, Publ. Hith Rep., Wash. 79, 147, 1964.

32. U.S. Public Health Service: National Office of Vital Statistics: Death rates for selected causes by age, color and sex: United States and each State 1949-51, all causes, Vital Statist. Spec. Rep. 49, 1, 1958.

33. Rose, G.: Cardiovascular mortality among American Negroes, Arch. environm. Hlth 5, 412, 1962 .

34. SaUer, H. I. and Enterline, P. E.: Are geographic variations in death rates for the cardiovascular diseases real? J. chron. Dis. 10, 513, 1959.

35. Enterline, P. E., RikLi, A. E., Sauner, H. I. and Hyman, M.: Death rates for coronary heart disease in metropolitan and other areas, Publ. Hlth Rep., Wash. 75, 759, 1960.

36. ENTERLINE, P. E. and STEWART, W. H.: Geographic patterns in deaths from coronary heart disease, Publ. Hlth Rep., Wash. 71, 849, 1956.

37. Chase, H. C.: Variations in heart disease mortality among counties of New York State, Publ. Hlth Rep., Wash. 78, 527, 1963.

38. SAUER, H.I.: Epidemiology of cardiovascular mortality-geographic and ethnic, Amer.J. publ. Hlth 52, 94, 1962.

39. Banta, J. E.: Personal communication.

40. Anitschkow, N.: Pathologische Anatomie and allgemeine Pathologie der Arteriosklerose, in Comptes rendus de la deuxieme conférence de pathologie géographique. (Ed. by AsHKaNAzY, M., OOSTHOEK, A. and UTREChT, S. A., Utrecht,) 26-28 Juillet 1934.

41. KeYs, A.: Problems and challenges, in Cardiovascular Epidemiology. (Ed. by KeYs, A. and WhITE, P. D.). Hoeber-Harper, New York, 1956.

42. Puffer, R. R. and Verhoestraete, L. J.: Mortality from cardiovascular diseases in various countries, with special reference to atherosclerotic heart disease. A preliminar y analysis, Bull. Wld Hlth Org. 19, 315, 1958.

43. Burgess, A. M., Jr., Fejfar, Z. and Kagan, A.: The problem of international comparability, Chron. Wld Hlth Org. 16, 437, 1962.

44. Morris, J. N.: Recent history of coronary disease, Lancet 1, 1 and 69, 1951.

45. MaRTIN, W. J.: The distribution in England and Wales of mortality from coronary disease, Brit. med.J. 1, 1523, 1956.

46. Campbell, M.: Death rate from diseases of the heart, 1876 to 1959, Brit. med.J. 2, 528, 1963.

47. Campbell, M.: The main cause of increased death rate from diseases of the heart, 1920 to 1959, Brit. med.J. 2, 712, 1963.

48. Keys, A., Karvonen, M. J. and Fddanza, F.: Serum cholesterol studies in Finland, Lancet 2, $175,1958$.

49. Acheson, R. M. and Thornton, E. H.: Mortality from coronary artery disease and 'myocardial degeneration' in the Republic of Ireland, Brit.J. prev. soc. Med. 12, 82, 1958.

50. Holman, R. L., Brown, B. W., Gore, I., McMillan, G. C., Paterson, J. C., Pollock, O. J., RoBerTs, J. C. and WissLer, R. W.: An index for the evaluation of arteriosclerotic lesions in the abdominal aorta, Circulation 22, 1137, 1960.

51. KaGAN, A. and UemurA, K.: Grading atherosclerosis in aorta and coronary arteries obtained at autopsy, Bull. Wld Hlth Org. 27, 667, 1962.

52. Moses, C.: Atherosclerosis, Mechanisms as a Guide to Prevention, p. 11. Lea \& Febiger, Philadelphia, 1963.

53. Enos, W. F., Jr., Beyer, J. C. and Holmes, R. H.: Pathogenesis of coronary disease in American soliders killed in Korea, J. Amer. med. Ass. 158, 912, 1955. 
54. Strong, J. P. and McGirl, H. C., Jr.: The natural history of coronary atherosclerosis, Amer. J. Path. 40, 37, 1962.

55. MCGILL, H.: Epidemiology of atherosclerosis: pathologic aspects. Presented at the Annual Meeting of the Council on Arteriosclerosis, American Heart Association, Los Angeles, 25 October 1963.

56. RoRerts, J. C., Moses, C. and Wir kins, R. H.: Autopsy studies in atherosclerosis, Circulation $20,511,520$ and $527,1959$.

57. Spain, D. M. and Bradess, V. A.: Postmortem studies on coronary atherosclerosis in one population group, Dis. Chest 36, 397, 1959.

58. Allison, R. B., Rourigues, F. L., Higgins, E. A., Jr., Leddy, J. P., Abelmann, W. H., Ellis, L. B. and RoBBrNs, S. L.: Clinicopathologic correlations in coronary atherosclerosis. Four hundred and thirty patients studied with postmortem coronary angiography, Circulation 27, 170, 1963.

59. Strong, J. P. and McGill, H., Jr.: The natural history of aortic atherosclerosis: Relationship to race, sex and coronary lesions in New Orleans, Exp. molec. Path. (Suppl.) 1, 15, 1963.

60. Spickerman, R. E., Brandendurg, J. T., Achor, R. W. P. and Edwards, J. G.: Incidence of coronary artery disease at necropsy in a community of 30,000, Circulation 22, 816, 1960.

61. Strong, J. P.: Inter-American studies of pathology, Proc. roy. Soc. Med. 55, 274, 1962.

62. Florentin, R. A., Lee, K. T., Daoud, A. S., Davies, J. N. P., Hall, E. W., and Goodale, F.: Geographic pathology of arteriosclerosis: A study of the age of onset of significant coronary arteriosclerosis in adult Africans and New Yorkers, Exp. molec. Path. 2, 103, 1963.

63. Shaper, A., Lee, K. T., Scott, R. F., Goodale, F. and Thomas, W. A.: Chemico-anatomic studies in the geographic pathology of arteriosclerosis. Comparison of adipose tissue fatty acids and plasma lipids in diabetics from East Africa and the United States with different frequencies of myocardial infarction, Amer.J. Cardiol. 10, 390, 1962.

64. Robertson, W. B.: Atherosclerosis and ischaemic heart disease. Observations in Jamaica, Lancet 1, 444, 1959.

65. Groom, D., McKee, E. E., Adrins, W., Pean, V. and Hudicourt, E.: Developmental patlems of coronary and aortic atherosclerosis in young Negroes of Haiti and the United States, Ann. intern. Med. 61, 400, 1964.

66. World Health Organization: Classification of atherosclerotic lesions: report of a study group, Wld Hlth Org. techn. Rep. Ser. No. 143, 1958.

67. Tejada, C., Gore, I., Strong, J. P. and McGill, H. C., Jr.: Comparative severity of atherosclerosis in Costa Rica, Guatemala and New Orleans, Circulation 18, 92, 1958.

68. Raghavan, P., Gandhi, M. J. and Nagendra, A. S.: Clinical epidemiology of myocardial infarction; a study of autopsy material of the K.E.M. Hospital from 1931 to 1960 and clinical material from 1951 to 1960, in Seminar on Atherosclerosis and Ischaemic Heart Disease. Dec. 19-21, 1961, Indian Counc. Med. Res. Spec. Rep. Ser. New Delhi, 1962.

69. Mathur, K. S., PATney, N. L. and Kumar, V.: Atherosclerosis in India. An autopsy study of the aorta and the coronary cerebral, renal and pulmonary arteries, Circulation 24, 68, 1961.

70. Wig, K. L., Malhotra, R. P., Chitkara, N. L. and Gupta, S. P.: Prevalence of coronary atherosclerosis in Northern India, Brit. med.J. 1, 510, 1962.

71. LANSING, A. I.: Atherosclerosis and the nature of the arterial wall, Circulation 24, 1283, 1961.

72. Duguid, J. B.: Etiology of atherosclerosis, Practitioner 175, 241, 1955.

73. Pickering, G.: Pathogenesis of myocardial and cerebral infarction: Nodular arteriosclerosis, Brit.med.J. 1, 517, 1964.

74. Morris, J. N. and CraWford, M. D.: Atherosclerosis and coronary heart disease, Lancet 1. 47, 1961.

75. Branwood, A. W. and Montgomery, G. L.: Observations on the morbid anatomy of coronary artery disease, Scot. med.J. 1, 367, 1956.

76. Crawford, T., Dexter, D. and Teare, R. D.: Coronary artery pathology in sudden death from myocardial ischaemia, Lancet 1, 181, 1961.

77. Mrtchell, J. R. A. and Schwartz, C. J.: The relation between myocardial lesions and coronary artery disease. II. A selected group of patients with massive cardial necrosis or scarring, Brit. Heart. J. 21, 1, 1963.

78. Morrus, J. N. and Crawford, M. D.: Coronary heart disease and physical activity of work Brit. med.J. 2, 1485, 1958.

79. MASON, J. K.: Asymptomatic disease of coronary arteries in young men, Brit. med.J. 2, 1234, 1963.

80. Blackburn, H., Keys, A., Simonson, E., Rautaharju, P. and Punsar, S.: The electrocardiogram in population studies. A classification system, Circulation 21, 1160, 1960. 
81. Rose, G. A.: The diagnosis of ischaemic heart pain and intermittent claudication in field surveys, Bull. Wld Hlth Org. 27, 645, 1962.

82. Burgess, A. M., Jr., Fejfar, Z. and KaGan, A.: Arterial hypertension and ischaemic heart disease. Comparison in epidemiological studies, Chron. Wld Hlth Org. 16, 437 and 441, 1962; 17,15 and $55,1963$.

83. Higgins, I. T. T., Cochrane, A. L. and Thomas, A. J.: Epidemiological studies of coronary disease, Brit. J. prev. soc. Med. 17, 153, 1963.

84. Frank, C. W., Weindlatt, E., Shapiro, S., Seiden, G. E. and Sager, R. V.: The H.I.P. study of incidence and prognosis of coronary heart disease: Criteria for diagnosis, J. chron. Dis. 16, $1293,1963$.

85. Schmitt, O. H. and Simonson, E.: The present status of vectorcardiography, Arch intern. Med. 96, 574, 1955.

86. Johnsron, F. D.: The clinical value of vectorcardiography, Circulation 23, 297, 1961.

87. Simonson, E.: Differentiation between Normal and Abnormal in Electrocardiography. Mosby, St. Louis, 1961.

88. Pipberger, H. V.: Use of computers in interpretation of electrocardiogams, Circulat. Res. 11, $555,1962$.

89. Wilkinson, R. S., Jr., Rabinowitz, R., Meltzer, S. and Abildskov, J. A.: Clinical observations with an orthogonal lead system, Circulation 25, 43, 962.

90. Oliver, M. F., Samuel, E., Morley, P., Young, G. B. and Kapur, P. L.: Detection of coronary-artery calcification during life, Lancet 1, 891, 1964.

91. RAAB, W.: Metabolic protection and reconditioning of the heart muscle through habitual physical exercise, Ann. intern. Med. 53, 87, 1960.

92. EAVenson, E., SCHNeider, A. J., Willis, M. J. and Cooper, G. R.: Cholesterol determination as a model for laboratory improvement and standarization of biochemical tests, Postgrad. Med. 34, 34, 1963.

93. Rose, G. A., Holland, W. W. and Crowley, E. A.: A sphygmomanometer for epidemiologists, Lancet 1, 296, 1964.

94. Garrow, G. S.: Zero muddler for unprejudiced sphygmomanometry, Lancet 2, 1205, 1963.

95. MARr, J. W., Heady, J. A. and Morris, J. N.: Repeat individual weighed dietary surveys, Proc. Nutr. Soc. 12, 18, 1959.

96. Cantoni, M., Paffenbarger, R. S. and Krueger, D. E.: Methods of dietary assessment in current epidemiologic studies of cardiovascular diseases, Amer. J. publ. Hith 51, 70, 1961.

97. Charvat, J., Dell, P. and Folkow, B.: Mental factors and cardiovascular diseases. Unpublished report of a conference, Cardiovascular Diseases Unit, World Health Organization, Geneva, 1962.

98. American Heart Association: Application of computers in cardiovascular disease, Circulat. Res. 11, 485, 1962.

99. Hayes, O. B., Abraham, S. and Caceres, C. A.: Use of computers in epidemiologic dietary studies, J. Amer. diet. Ass. 44, 456, 1964.

100. CADY, L., Woodbury, M., Gertler, M. and Fick, G.: Mass screening of cardiograms, Amer. J. publ. Hlth 52, 1872, 1962.

101. Caceres, C. A., Steinberg, C. A., Abraham, S., Carbery, W. J., McBride, J. M., Tolles, W. E. and RIKLI, A. E.: Computer extraction of electrocardiographic parameters, Circulation $25,356,1962$.

102. DaWBer, T. R., Moore, F. E. and MANN, G. V.: Coronary hcart discasc in the Framingham study, Amer.J. publ. Hlth 47 (Suppl. 4) 4, 1957.

103. Doyle, J. T., Heslin. S.,HILleboe, H. E. and Formel, P. F.: Early diagnosis of ischaemic heart disease, New Engl.J. Med. 261, 1096, 1959.

104. Chapman, J. M., Goerke, L. S., Dxxon, W., Loveland, D. B. and Phillips, E.: The clinical status of a population group in Los Angeles under observation for two to three years, Amer. $J$. publ. Hlth 47 (Suppl. 4) 33, 1957.

105. TAUBER, J. and THOMrson, D. J.: The prevalence of disease of the heart in an urban center as estimated from medical examination of a probability sample, J. chron. Dis. 6, 595, 1957.

106. Epstein, F. H., BoAs, E. P. and Simpson, R.: The epidemiology of atherosclerosis among a random sample of clothing workers of different ethnic origins in New York City. I. Prevalence of atherosclerosis and associated characteristics. II. Associations between manifest atherosclerosis, serum lipid levels, blood pressure, overweight and some other variables, J. chron. Dis. 5,300 and $329,1957$.

107. Stamler, J., Lindberg, H. A., Berkson, D. M., Shaffer, A., Miller, W. and Poindexter, A.: Prevalence and incidence of coronary heart diseases in strata of the labor force of a Chicago industrial corporation, J. chron. Dis. 11, 405, 1960. 
108. Paul, O., Lepper, M. H., Phelan, W. H., Dupertuis, G. W., MacMillan, A., McKean, H. and PARK, H.: A longitudinal study of coronary heart disease, Circulation 28, 20, 1963.

109. MCDonough, J. R., Hames, C. G., Stulb, M. S. and Garrison, G. E.: Coronary heart disease among Negroes and whites in Evans County, Georgia, J. chron. Dis. 18, 443, 1965.

110. Epstein, F. H., Francis, T., Jr., Hayner, N. H., Johnson, B. C., KJelsberg, M. O., Napier, J. A., Ostrander, L. D., Jr., Payne, N. W. and Dodge, H. J.: The distribution of selected physiological variables and pathological states in a total community-Tecumseh, Michigan. Amer. J. Epidemiol. 81, 307, 1965.

111. UNGerLeIDER, H. E.: The prognostic implications of the electrocardiogram, in Annals of Life Insurance Medicine, Ed. by Higgins, E. V., Jecklin, H., TANNer, E. and UNGerleider, H. E. Springer, Berlin, 1962.

112. Higgins, I. T. T.: Unpublished data from Framingham study.

113. Stamler, J.: Atherosclerotic coronary heart disease. The major challenge to contemporary public health and preventive medicine, Conn. Med. 28, 675, 1964.

114. U.S. Public Health Service: National Center for Health Statistics: Heart disease in adults, United States 1960-1962, Publ. Hlth Serv. Publ. No. 1000, Ser. 11, No. 6, Washington D.C., 1964.

115. WyLIE, C. M.: Screening for cardiovascular disease in Baltimore, Ann. intern. Med. 48, 1070, 1958.

116. Commission on Chronic Illness: Chronic Illness in a Large City-The Baltimore Study, Vol. IV. Harvard University Press, Cambridge, Mass., 1957.

117. Commission on Chronic Illness: Chronic Illness in a Rural Area-The Hunterdon Study, Vol. III. Harvard University Press, Cambridge, Mass., 1959.

118. White, K. L. and Ibrahim, M. A.: The distribution of cardiovascular disease in the community, Ann. intern. Med. 58, 627, 1963.

119. WILsON, J. M. G.: Multiple screening, Lancet 2, 51, 1963.

120. U.S. Public Health Service: Health Statistics from the U.S. National Health Survey: Heart conditions and high blood pressure reported in interviews, Publ. Hlth Serv. Publ. No. 584-B13, Washington, D.C. 1960.

121. Thompson, D. J. and TAUner, J.: Household survey, individual interviews and clinical examination to determine prevalence of heart disease, Amer. J. publ. Hlth 47, 1131, 1957.

122. U.S. Public Health Service: Health Statistics from the U.S. National Health Survey; Evaluation of a single visit cardiovascular examination, Publ. Hlth Serv. Publ. No. 584-D7, Washington, D.C., 1961.

123. Fulmer, H. S. and Roberts, R. W.: Coronary heart disease among the Navajo Indians, Ann. intern. Med. 59, 740, 1963.

124. WYNDER, E. L., LemON, F. L. and BRoss, I. J.: Cancer and coronary artery diseases among Seventh-Day Adventists, Cancer 12, 1016, 1959.

125. Barrow, J. G., Quinlan, C. B., Cooper, G. R., Whitney, V. S. and Goodloe, M. H. R.: Studies in atherosclerosis. III. An epidemiological study of atherosclerosis in Trappist and Benedictine Monks: A preliminary report, Ann. intern. Med. 52, 368, 1960.

126. Kannel, W. B., Kagan, A., Dawber, T. R. and Revotskie, N.: Epidemiology of coronary heart disease, Geriatrics 17, 675, 1962.

127. Pelt, S. and D'Alonzo: Acute myocardial infarction in a large industrial population. J. Amer. med. Ass. 185, $117,1963$.

128. Zukel, W. J., Lewis, R. H., Enterline, P. E., Patnter, R. C., Ralston, L. S., Fawcett, R. M., Meredith, A. P. and Peterson, B.: A short-time community study of coronary heart disease: A preliminary report on the North Dakota study, Amer.J. publ. Hlih 49, 1630, 1959.

129. Eisenberg, H., Feltner, W. R., Payne, G. H. and Haddad, C. A.: The epidemiology of coronary heart disease in Middlesex County, Connecticut. I. A preliminary report on methodology and the incidence of primary myocardial infarction, J. chron. Dis. 14, 221, 1961.

130. Rosenman, R. H., Friedman, M., Straus, R., Wurm, M., Kositchek, R., Hahn, W. and Werthessen, N.: The Western Collaborative Study Group: A study of predictive factors in the occurrence of coronary heart disease (interim report). Presented at the Annual Meeting of the American Heart Association, Los Angeles, California, October, 1963.

131. Morris, J. N., Heady, J. A., Raffle, P. A. B., Roberts, C. G. and Parks, J. W.: Coronary heart disease and physical activity of work, Lancet 2, 1053 and 1111, 1953.

132. VAN Buchem, F. S. P.: Atherosclerosis and nutrition, Nutr. et Dieta 4, 122, 1962.

133. LEW, E. A.: Biostatistical pitfalls in studies of atherosclerotic heart disease, Fed. Proc. 21, II, (Suppl. 11) 62, 1962. 
134. Thomas, A. J., Cochrane, A. L. and Higgins, I. T. T.: The measurement of the prevalence of ischaemic heart disease, Lancet 2, 540, 1958.

135. KENNEDY, A. C. and CowAN, B.: Further observations on the incidence of coronary heart disease in a rural area in southwest Scotland, Scot. Med.J. 3, 283, 1958.

136. ACHeson, R. M.: Aetiology of coronary heart disease in old men, Brit. J. prev. soc. Med. 15,49, 1961.

137. Brown, R. G., Davidson, L. A. G., McKeown, T. and Whitfield, A. G. W.: Coronary artery disease. Influences affecting its incidence in males in the seventh decade, Lancet 2, 1073, 1957.

138. Drolier, H. and Pemberton, J.: Cardiovascular disease in a random sample of elderly people, Brit. Heart.J. 15, 199, 1953.

139. Holland, W. W.: Personal communication.

140. Holland, W. W.: Unpublished data.

141. Rautaharju, P. M., Karvonen, M. J. and Keys, A.: The frequency of arteriosclerotic and hypertensive heart disease among ostensibly healthy working populations in Finland, J. chron. Dis. 13, 426, 1961.

142. Heyden, S.: Personal communication.

143. FoDor, J.: Personal communication. :

144. KEYS, A.: Diet and coronary heart disease throughout the world, Cardiol. prat. 13, 225, 1962.

145. Brorck, G., Blomquist, G. and Sievers, J.: Studies on myocardial infarction in Malmo 1935 to 1954. IV. Myocardial infarction in the hospital in relation to coronary heart disease in the population, Acta med. scand. 165, 1, 1959.

146. Sievers, J. and Blomquist, G.: Continued studies on myocardial infarction in Malmo. Our 1935 to 1954 material completed for the years 1955 to 1959, Acta med. scand. 172, 187, 1962.

147. Miasnikov, A. L.: Atherosclerosis; occurrence, clinical forms, therapy. Translation sponsored and distributed by National Neart Institute, National Institutes of Health, Bethesda Maryland, 1962.

148. Symposium on Epidemiology of Heart Disease, Amer. J. Cardiol. 10, 315-446, 1962.

149. KEYs, A.: The role of the diet in human atherosclerosis and its complications, in Atherosclerosis and its Origin, p. 263. Ed. by SANDler, M. and Bourne, G. H. Academic Press, New York, 1963.

150. Strong, J. P., Watnwrighr, J. and MCGill, H. C.: Atherosclerosis in the Bantu, Circulation 20, 1118, 1959.

151. Anderson, M., Walker, A. R. P., Lutz, W. and Higginson, J.: Chemical and pathological studies on aortic atherosclerosis. A comparison study of 128 aortas in South African Bantu and white subjects, Arch. Path. 68, 380, 1959.

152. BRoCK, J. F. and Gordon, H.: Ischaemic heart disease in African populations, Postgrad. med. J. 35, 223, 1959.

153. Antonis, A. and Bersohn, I.: Serum triglyceride levels in South African Europeans and Bantu and in ischaemic heart disease, Lancet 1, 998, 1960.

154. Thomas, W. A., Davies, J. M. P., O'Neal, R. N. and Dimakulangan, A. A.: The incidence of myocardial infarction correlated with venous and pulmonary thrombosis and embolism. A geographic study based on autopsies in Uganda, East Africa and St. Louis, U.S.A., Amer. J. Cardiol. 5, 41, 1960.

155. LaUrie, W., WoODs, J. D. and ROACH, G.: Coronary heart disease in the South African Bantu, Amer. J. Cardiol. 5, 48, 1960.

156. Hathorn, M., Gillman, T. and Campbell, G. T.: Blood lipids, mucoproteins and fibrinolytic activity in diabetic Indians and Africans in Natal. Possible relation to vascular complications, Lancet 1, 1314, 1961.

157. Miller, D. C., Spencer, S. S. and White, P. D.: Survey of cardiovascular disease among Africans in the vicinity of the Albert Schweitzer Hospital in 1960, Amer.J. Cardiol. 10, 432, 1962.

158. Wainwright, J.: Atheroma in the African (Bantu) in Natal, Lancet 1, 366, 1961.

159. ManN, G. V., Roels, O. A., Price, D. L. and Merrill, J. M.: Cardiovascular disease in African pygmies-a survey of the health status, serum lipids and diet of pygmies in the Congo, J. chron. Dis. 15, 341, 1962.

160. REEF, $H$. and IsAaCson, $C_{\text {. }}$ : Atherosclerosis in the Bantu. The distribution of atheromatous lesions in Africans over 50 years of age, Circulation 25, 66, 1962.

161. Seftel, H. C., Keeley, K. J. and WAlker, A. R. P.: Characteristics of South African Bantu who have suffered from myocardial infarction, Amer. J. Cardiol. 12, 148, 1963.

162. Dreyfuss, F., TOOR, M., AGMON, J. and ZlotnICK, A.: Observations on myocardial infarction in Israel, Cardiologia 30, 387, 1957. 
163. Toor, M., Katchalsky, A., Agmon, J. and Allalouf, D.: Serum lipids and atherosclerosis among Yemenite immigrants in Israel, Lancet 1, 1270, 1957.

164. KALLNER, G.: iEpidemiology of arteriosclerosis in Israel, Lancet 1, 1155, 1958.

165. BRUNNER, D. M. and MANELIS, G.: Myocardial infarction among members of command settlements in Israel, Lancet 2, 1049, 1960.

166. ToOr, M., Katchar.sky, A., AGmon, J. and Air.ainiff, D.: Atherosclerosis and related factors in immigrants in Israel, Circulation 22, 265, 1960.

167. Cohen, A. M. and Barly, S. and Poznanski, R.: Change of diet of Yemenite Jews in relation to diabetics and ischaemic heart disease, Lancet $2,1399,1961$.

168. Schwartz, M. J., Rosensweig, B., Toor, M. and Lewitus, Z.: Lipid metabolism and arteriosclerotic heart disease in Israelis of Bedouin Yemenite and European origin, Amer. J. Cardiol. 12, 157, 1963.

169. Groen, J. and Medalie, J.: Field studies in progress in Israel.

170. Gopalan, C. and Ramanthan, K. S.: Fats and disease (letter to the Editor), Lancet 2, 1212, 1956.

171. Padmavati, S., Gupta, S. and Pantulu, G. V. A.: Dietary fat, serum cholesterol levels and incidence of atherosclerosis and hypertension in Delhi, Indian J. med. Res. 46, 245, 1958.

172. Padmavati, S., Gupta, S. and Pantulu, G. V. A.: Dietary fat, serum cholesterol levels and incidence of atherosclerosis in Delhi, Circulation 19, 849, 1959.

173. Mathur, K. S.: Environmental factors in coronary heart disease. An epidemiologic study at Agra, India, Circulation 21, 684, 1960.

174. Padmavati, S., Gupta, S., Pantulu, G. V. A. and Lakhanpal, R. K.: Epidemiologic studies in Faridabad, Indian Heart J. 13, 275, 1961.

175. Padmavati, S.: Epidemiology of cardiovascular disease in India. II. Ischemic heart disease, Circulation 25, 711, 1962.

176. Padmavati, S., Gupta, S. and Pantulu, G. V. A.: Dietary fat, serum cholesterol levels and incidence of atherosclerosis and hypertension in Delhi, India, Amer. Heart J. 56, 112, 1958.

177. Seminar on atherosclerosis and ischaemic heart disease, Indian Counc. Med. Res. Spec. Rep. Ser., New Delhi, 1962.

178. VAKIL, R. J.: Cardiovascular diseases in India, Amer. J. Cardiol. 10, 380, 1962.

179. Gordon, T.: Mortality experience among the Japanese in the United States, Hawaii and Japan, Publ. Hlth Rep., Wash. 72, 543, 1957.

180. Keys, A., Kimura, N., Kusurawa, A., Bronte-Stewart, B., Larsen, N. and Keys, M. H.: Lesions from serum cholesterol studies in Japan, Hawaii and Los Angeles, Ann. intern. Med. 48, $83,1958$.

181. GoRe, I., NAKashima, T., IMAI, T. and WHITE, P. D.: Coronary atherosclerosis and myocardial infarction in Kyushu, Japan, and Boston, Massachusetts, Amer. J. Cardiol. 10, 400, 1962.

182. Ueda, H.: Cardiovascular diseases in Japan, Amer. J. Cardiol. 10, 371, 1962.

183. SAGAN, L. A. and Seiget, D. G.: Adult health study; clinical and laboratory data, 1958-1960, Techn. Rep. 12-63, Atomic Bomb Casualty Commission, Nagasaki.

184. Tung, C-L., WU, K-H. and WANG, C-Y.: Coronary atherosclerosis in Eastern China, China med.J. 77, 596, 1958.

185. Lru, C. K.: Cardiovascular diseases in China, Amer.J. Cardiol. 10, 367, 1962.

186. Almurung, M. M.: Heart disease in the Philippines, Amer. J. Cardiol. 10, 362, 1962.

187. Adamson, L. F.: Serum cholesterol concentrations of various ethnic groups in Hawaii, J. Nutr. $71,27,1960$.

188. Bennett, C., Fokuyama, G. and McBride, T.: Cardiovascular-renal mortality in Hawaii, Amer.J. publ. Hlth 52, 1418, 1962.

189. Rojas Villegas, F.: Epidemiology of cardiovascular disease in the Pacific area, Jap. Heart J. $3,117,1962$.

190. Hunter, J. D.: Diet, body build, blood pressure and serum cholesterol levels in coconut-eating Polynesians, Fed. Proc. 21, II, (Suppl. 11), 36, 1962.

191. Whyte, H. M., Graham, A. D. and DeWolfe, M. S.: Body fat, blood pressure and serum cholesterol of Australian men, Aust. Ann. Med. 7, 328, 1958.

192. Prior, I.: A health survey in a rural Maori community, with particular emphasis on the cardiovascular, nutritional and metabolic findings, N.Z. med.J. 61, 333, 1962.

193. Scrimshaw, N. S., Trulson, M., Tejada, C., Hegsted, M. and Stare, F. J.: Serum lipoprotein and cholesterol concentrations; comparison of rural Costa Rica, Guatemalan, and U.S. populations, Circulation 15, 805, 1957.

194. Del Campo, E. and Rojas Vinlegas, F.: Personal communication. 
195. Stuart, K. L., Schneckloth, R. E., Lewis, L. A., Moore, F. E. and Corcoran, A. C.: Diet, serum cholesterol, protein, blood hemoglobin and glycosuria in a West Indian community (St. Kitts, W.I.), Brit. med.J. 2, 1283, 1962.

196. RobERTSON, W. B.: Some factors influencing the development of atherosclerosis. A survey in Jamaica, West Indies, J. Atheroscler. Res. 2, 79, 1962.

197. Miall, W. E.: Personal communication.

198. Epstein, F. H.: Epidemiological studies on the nature of high blood pressure, in Renal Metabolism and Epidemiology of Renal Diseases. (Ed. by MetCoff, J.). National Kidney Disease Foundation, New York, 1964.

199. Frfedman, L. R. and Fukushima, K.: Nat. Inst. Health Adult Health Study (in preparation). Atomic Bomb Casualty Commission, Japan.

200. Yano, K. and Ueda, S.: Coronary heart disease in Hiroshima, Japan, Yale J. Biol. Med. 35, 504, 1963.

201. Scrimshaw, N. S., Balsam, H. and Arroyave, G.: Serum cholesterol levels in school children from three socio-economic groups, Amer.J. clin. Nutr. 5, 629, 1957.

202. LoWENSTEIN, F. W.: Epidemiologic investigations in relation to diet in groups who show little atherosclerosis and are almost free of coronary ischaemic heart disease, Amer. J. clin. Nutr. 15, $175,1964$.

203. LiLIENFELD, A. M.: Epidemiological methods and inferences in studies of non-infectious diseases, Publ. Hlth Rep., Wash. 72, 51, 1957.

204. Epstern, F. H., Simpson, R. and BoAs, E. P.: The epidemiology of atherosclerosis among a random sample of clothing workers of different ethnic origins in New York City. II. Associations between manifest atherosclerosis, serum lipid levels, blood pressure, overweight, and some other variables, J. chron. Dis. 5, 329, 1957.

205. KEYS, A.: Epidemiologic aspects of coronary artery disease, J. chron. Dis. 6, 552, 1957.

206. GoRdon, H.: The regulation of the human serum cholesterol level, Postgrad. med.J. 35, 186, 1959.

207. KeYs, A. and FIDANZA, F.: Serum cholesterol and relative body weight of coronary patients in different populations, Circulation 22, 1091, 1960.

208. Keys, A., Taylor, H. L., Blackburn, H., Brozek, T., Anderson, J. T. and Simonson, E.: Coronary heart disease among Minnesota business and professional men followed fifteen years, Circulation 28, 381, 1963.

209. Kagan, A., Kannel, H. B., Dawber, T. R. and Revotskie, N.: The coronary profile, Ann. N.Y. Acad. Sci. 97, 883, 1963.

210. Chapman, J. M. and Massey, F. J.: The interrelationship of serum cholesterol, hypertension body weight, and risk of coronary disease: Results during first ten years' follow-up in the Los Angeles heart study, J. chron. Dis. 17, 933, 1964.

211. The Technical Group and Committee on Lipoproteins and Atherosclerosis: Evaluation of serum lipoprotein and cholesterol measurements as predictors of clinical complications of atherosclerosis, Circulation 14, 691, 1956.

212. Marks, H. H.: Influence of obesity on morbidity and mortality, Bull. N.Y. Acad. Med. 36, 296, 1960.

213. KeYs, A.: Obesity and degenerative heart disease, Amer. J. publ. Health. 44, 864, 1954.

214. CADY, L. D., Jr., GERTLER, M. M., GotTSCH, L. G. and WOODBURY, M. A.: The factor structure of variables concerned with coronary artery disease, Behav. Sci. 6, 37, 1961.

215. Doll, R. and HiLl, A. B.: Lung cancer and other causes of death in relation to smoking, Brit. med.J. 2, 1071, 1956.

216. Bufchley, R. W., Drake, R. M. and Breslow, L.: Relationship of amount of cigarette smoking to coronary heart disease mortality rates in men, Circulation 18, 1085, 1958.

217. Hammond, E. C. and HoRN, D.: Smoking and death rates--report on forty-four months of follow-up of 187,783 men, J. Amer. med. Ass. 166, $1159,1958$.

218. Wynder, E. L. and Lemon, F. R.: Cancer, coronary artery disease and smoking. A preliminary report on differences in circumstances between Seventh-Day Adventists and others, Calif. Med. 89, 267, 1958.

219. DorN, H. F.: Tobacco consumption and mortality from cancer and other diseases, Publ. Hlth Rep., Wash. 74, 581, 1959.

220. SpaIN, D. M. and NATHAN, D. J.: Smoking habits and coronary atherosclerotic heart disease, J. Amer. med. Ass. 177, 683, 1961.

221. Doyi., .. T., Dawber, T. R., Kannel, W. B., Heslin, A. S. and Knhn, H. A.: Cigarette smoking and coronary heart disease: Combined experience of the Albany and Framingham studies, New Engl.J. Med. 226, 796, 1962; J. Amer. med. Ass. 190, 886, 1964. 
222. Report of the Advisory Committee to the Surgeon General of the Public Health Service. Smoking and health, Publ. Hlth Serv. Publ. No. 1103. U.S. Govt. Printing Office, Washington, D.C., 1964.

223. Blackburn, H., Brozek, J. and Taylor, H. L.: Common circulatory measurements in smokers and non-smokers, Circulation 22, 1112, 1960.

224. Bronte-Stewart, B.: Cigarette smoking and ischaemic heart disease, Brit. med.J. 2, 379, 1961.

225. Kontrinen, A.: Cigarette smoking and serum lipids in young men, Brit. med.J. 1, 1115, 1962.

226. Ahrens, E. H., Jr., Hirsch, J., Oette, K., Farquhar, J. W. and Stein, Y.: Carbohydrateinduced and fat-induced lipemia, Trans. Ass. Amer. Phycns. 74, 134, 1961.

227. Knittle, J. L. and Ahrens, E. H., Jr.: Carbohydrate metabolism in two forms of hyperglyceridemia, J. clin. Invest. 43, 485, 1964.

228. Swell, L. and Treadwell, C. R.: Interrelationships of lipids in blood and tissues, in Atherosclerosis and its Origin, p. 301 . Ed. by SANDERs, M., and Bourne, G. H. Academic Press, New York, 1963.

229. Symposium on atromid, J. Atheroscler. Res. 3, Nos. 5-6, 1963.

230. Albrink, M. J., Meigs, J. W. and Man, E. B.: Serum lipids, hypertension and coronary artery disease, Amer. J. Med. 31, 4, 1961.

231. Carlson, L. A.: Serum lipid in men with myocardial infarction, Acta med. scand. 167, 399, 1960.

232. SCHAEFER, L. E.: Serum cholesterol-triglyceride distribution in a 'normal' New York City population, Amer.J. Med.36, 262, 1964.

233. SCHRADE, W. and BôHLE, E.: On hyperlipidaemia and atherosclerosis, J. Atheroscler. Res. $2,161,1962$.

234. Canellos, G. P. and Hatch, F. T.: Metabolic studies in young males with coronary heart disease, Circulation, 26, 648, 1962.

235. Brown, D. F., HesLiN, A. S. and Doyle, J. T.: Fasting and postprandial serum triglyceride levels in healthy young Americans, Amer.J. clin. Nutr. 13, 1, 1963.

236. Albrink, M. J., Meigs, J. W. and Granoff, M. A.: Weight gain and serum triglycerides in normal men, New Engl. J. Med. 266, 484, 1962.

237. Albrink, M. J.: Rationale for treatment of hyperglyceridemia, Ann. intern. Med. 59, 581, 1963.

238. Vallance-Owen, J. and Ashton, W. L.: Cardiac infarction and insulin antagonism, Lancet 1, 1226, 1963.

239. MoRris, J. N.: Occupation and coronary heart disease, Arch. intern. Med. 104, 903, 1959.

240. Heady, J. A., Morris, J. N., KAgan, A. and Raffle, P. A. B.: Coronary heart disease in London busmen, Brit.J. prev. soc. Med. 15, 143, 1961.

241. Breslow, L. and Buell, P.: Mortality from coronary heart disease and physical activity of work in California, J. chron. Dis. 11, 421, 1960.

242. KAHN, H. A.: The relationship of reported coronary heart disease mortality to physical activity of work, Amer. J. publ. Hlth 53, 1058, 1963.

243. Taylor, H. L., Klepetar, E., Keys, A., Parlin, W., Blackburn, H. and Puchner, T.: Death rates among physically active and sedentary employees of the railroad industry, Amer. J. publ. Hlth 52, 1697, 1962.

244. Fox, S. M., III, and Skinner, J. S.: Physical activity and cardiovascular death, Amer. J. Cardiol. 14, 731, 1964.

245. Montoye, H. J.: Summary of research on the relationship of exercise to heart disease, I. Sport. Med. 2, 35, 1962.

246. Wilson, J. M. G. and Heasman, M. A.: Coronary artery disease-an epidemiological review. I., Mth. Bull. Minist. Hlth Lab. Serv. 18, 94, 1959.

247. Morris, J. N.: Coronary disease in England, Cardiol. prat. 13, 85, 1962.

248. Tyroler, H. A. and CASSEL, J.: Health consequences of cultural change. II. Effect of urbanization on coronary heart mortality in rural residents, J. chron. Dis. 17, 167, 1964.

249. Stout, C., Morrow, J., Brandt, E. N. and Wolf, S.: Unusually low incidence of death from myocardial infarction in an Italian-American community in Pennslyvania, J. Amer. med. Ass. 188, 845, 1964.

250. Syme, S. L., Hyman, M. M. and Enterline, P. E.: Some social and cultural factors associated with the occurrence of coronary heart disease, J. chron. Dis. 17, 277, 1961.

251. Stamler, J., KJelsberg, M., Hall, Y. and Scotch, N.: Epidemiologic studies on cardiovascular-renal disease. III. Analysis of mortality by age-sex-nationality, J. chron. Dis. 12, $464,1960$.

252. WARDWell, W. I., Hyman, M. and Bahnson, C. B.: Stress and coronary heart disease in three field studies, J. chron. Dis. 17, 73, 1964.

253. ShurtlefF, D.: Mortality among the married, J. Amer. Geriat. Soc. 4, 654, 1956. 
254. Kraus, A. S. and LilienFeld, A. M.: Some epidemiologic aspects of the high mortality rate in the young widowed group, J. chron. Dis. 10, 207, 1959.

255. ZALOKAR, J. B.: Marital status and major causes of death in women, J. chron. Dis. 11, 50, 1960.

246. ShePs, M. C.: Marriage and mortality, Amer. J. publ. Hlth 51, 547, 1961.

257. Skyrtng, A., Modan, B., Crocetti, A. and Hammerstrom, C.: Some epidemiological and familial aspects of coronary heart disease: Report of a pilot study, J. chron. Dis. 16, 1267, 1963.

258. RuSSEK, H. I.: Emotional stress and coronary heart disease in American physicians, dentists and laywers, in Memorias del IV. Congreso Mundial de Cardiologia, Tomo IV-B, p. 75, Mexico, Octobre, 1962.

259. Pell, S. and D'Alonzo, C. A.: Blood pressure, body weight, serum cholesterol and smoking habits among executives and non-executives, J. occup. Med. 3, 467, 1961.

260. Hinkle, L. E., Jr., Whitney, L. H., Lehman, E., Christenson, W. N. and Benjamin, B.: Occupational mobility, social background and coronary heart disease in a nationwide industry. Presented at the Conference on Cardiovascular Disease Epidemiology, American Heart Association, Chicago, Ill., 1-2 February 1964.

261. Ostfeld, A. M., Lebovits, R. B., SheKelle, R. B. and PAul, O.: A prospective study of the relationship between personality and coronary heart disease, J. chron. Dis. 17, 265, 1964.

262. Buell, P. and Breslow, L.: Mortality from coronary heart disease in California men who work long hours, J. chron. Dis. 11, 615, 1960.

263. Bainton, C. R. and Peterson, D. R.: Deaths from coronary heart disease in persons fifty years of age and younger: A community-wide study, New Engl.J. Med. 268, 569, 1963.

264. Rosenman, R. H. and FrIEdman, M.: Behavior patterns, blood lipids and coronary heart disease, J. Amer. med. Ass. 184, 934, 1963.

265. Westlake, P. T., Wilcox, A. A., Haley, M. I. and Peterson, J. E.: Relationship of mental and emotional stress to serum cholesterol levels, Proc. Soc. exp. Biol., N.Y. 97, 163, 1958.

266. Thomas, C. B. and MurPhy, E. A.: Further studies on cholesterol levels in the Johns Hopkins medical students: The effect of stress at examinations, J. chron. Dis. 8, 661, 1958.

267. Dreyfuss, F. and CZACZKES, J. W.: Blood cholesterol and uric acid of healthy medical students under stress of an examination, Arch. intern. Med. 103, 78, 1959.

268. Wolf, S., McCabe, W. R., Yamamoto, J., Adsett, A. A. and Schottsteadt, W. W.: Changes in serum lipids in relation to emotional stress during rigid control of diet and exercise, Circulation 26, 379, 1962.

269. Peterson, J., KeIth, R. and Wilcox, A.: Hourly changes in serum cholesterol concentration. Effects of the anticipation of stress, Circulation 25, 798, 1962.

270. PaGe, I. H., Monnuddin, M. and Lewis, L. A.: The effect of short-term stress (tournament bridge playing and performance of surgery) on serum lipids, J. Atheroscler. Res. 2, 62, 1962.

271. Sprague, H. B.: Emotional stress and the etiology of coronary artery disease, Circulation 17, 1, 1958.

272. RAAB, W.: Neurohormonal atherogenesis, Amer. J. Cardiol. 1, 113, 1958.

273. Wolf, S. (moderator): Emotional stress in coronary heart disease, N.Y. Med. 15, 826, 1959.

274. Conference on Culture, Society and Health: Sociocultural factors in chronic organic disease Ann. N.Y. Acad.Sci. 84, 789, 1960.

275. Sigler, L. A. (Editor): Emotional disturbance and myocardial infarction, Amer. J. Cardiol. 7, $757,1961$.

276. Fisher, S. H.: Psychological factors and heart disease, Circulation 27, 113, 1963.

277. EPSTEIN, F. H.: Hereditary aspects of coronary heart disease, Amer. Heart J. 67, 445, 1964.

278. EpSTeIN, F. H.: Genetic factors in atherosclerosis: Report to the Division on Atherosclersis (PAGE, I. H., Chairman), National Conference on Cardiovascular Diseases, November, 1964.

279. Epstein, F. H. and KJELSBERG, M. O.: Coronary heart disease in relation to blood pressure and cholesterol levels in population studies. Presented at Conference on "Contributions of Genetics to Epidemiologic Studies," U.S. Public Health Service and The University of Michigan, Ann Arbor, 1963, U.S. Govt. Printing Office. Public Health Service Publ. No. 1163, 1965.

280. Thomas, C. B.: Familial and epidemiologic aspects of coronary disease and hypertension, J. chron. Dis. 7, 198, 1958.

281. Francis, T., Jr.: Aspects of the Tecumseh study, Publ. Hlth Rep., Wash. 76, 963, 1961.

282. Epstrin, F. H.: Fpidemiological research in total communities: Settings and perspectives, Meth. Inform. in Med. 3, 18, 1964.

283. Symposium on thrombosis and anticoagulation, Amer. J. Med. 33, 619, 1962.

284. Mustard, J. F., Murphy, E. A., Rowsell, H. C. and Downie, H. G.: Platelets and atherosclerosis, J. Atheroscler. Res. 4, 1, 1964.

285. Oliver, M. F.: Metabolic factors in the aetiology of coronary heart disease, in Modern Trends in Cardiology, p. 172. (Ed. by MoRGan Jones, A.) Butterworths, London, 1960. 
286. Boyd, G. S.: The thyroid, iodothyronines and atherosclerosis, J. Atheroscler. Res. 1, 26, 1961.

287. Stamler, J.: The relationship of sex and gonadal hormones to atherosclerosis, in Atherosclerosis and its Origin, p. 231. Ed. by SANDLER, M. and Bourne, G. H. Academic Press, New York and London, 1963.

288. WinkelsteIn, W., Jr. and ReKate, A. C.: Age trend of mortality from coronary artery disease in women and observations on the reproductive patterns of those affected, Amer. Heart J. 67, $481,1964$.

289. SCHROEDER, H. A.: Relations between hardness of water and death rates from certain chronic and degenerative diseases in the United States, J. chron. Dis. 12, 586, 1960.

290. Morkis, J. N., Crawford, M. D. and Heady, J. A.: Hardness of local water supplies and mortality from cardiovascular disease, Lancet 1, 860, 1961.

291. MCCABE, L. J., Jr.: The correlations of drinking water quality and vascular disease. Presented at the Conference on Cardiovascular Disease Epidemiology: American Heart Association, Chicago Heart Association, National Heart Institute, Chicago, 2-3 Feb. 1963.

292. WASSERBURGER, R. H.: T-wave and tensions. Electrocardiographic changes of anxiety, Heart Bull. 9, 54, 1960.

293. Langner, P. H., Jr. and Geselowitz, D. B.: First derivative of the electrocardiogram, Circulat. Res. 10, 220, 1962.

294. CADY, L. D., Jr., GerTler, M. M. and Nowttz, L. A.: Coronary disease factors, Behav. Sci. 9, 30, 1964.

295. Stamler, J.: The early detection of heart disease, University of Michigan School of Public Health, Cont. Educ. Ser. No. 97, Ann Arbor, Michigan, 1962.

296. Paul, O.: Personal communication.

297. Epstein, F. H., Ostrander, L. D., Jr., Johnson, B. C., Payne, M. W., Hayner, N. S., Kellfr, J. B. and Francis, T., Jr.: Epidemiological studies of cardiovascular disease in a total community, Tecumseh, Michigan, Ann. intern. 62, 1170, 1965.

298. KANNEL, W. B.: Immediate mortality in coronary heart disease, in Memorias del IV. Congreso Mundial de Cardiologia, Tumo IV B, p. 176, Mexico, Octobre, 1962.

299. CoRNFIELD, J.: Joint dependence of risk of coronary heart disease on serum cholesterol and systolic blood pressure: A discriminant function analysis, Fed. Proc. 21, II (Suppl. 11), 58, 1962.

300. Ahrens, E. H., Jr., Hirsch, J., Insull, W., Jr., and Peterson, M. L.: Dietary fats and human serum lipid levels, in Chemistry of Lipides as Related to Atherosclerosis, p. 222. (Ed. by PAGE, I. H.). C. C. Thomas, Springfield, Illinois. 1958.

301. Kinsell, L. W., Michaels, G. D., Friskey, R. W. and Splttier, S.: Essential fatly acids, lipid metabolism and atherosclerosis, Lancet 1, 334, 1958.

302. Keys, A., Anderson, J. T. and Grande, F.: Serum cholesterol in man: Diet fat and intrinsic responsiveness, Circulation 19, 201, 1959.

303. Gerson, T., Shorland, F. B. and Adams, Y.: The effect of corn oil on the amount of cholesterol and the excretion of sterol in the rat, Biochem.J. 81, 584, 1961.

304. Spritz, N., Grundy, S. and Ahrens, E. H.: Studies on the mechanism of diet induced alterations of plasma cholesterol, J. clin. Invest. 42, 981, 1963.

305. Stamler, J., Berkson, D. M., Young, Q. D., Lindberg, H. A., Hall, Y., Mojonnier, L. and ANDELman, S. L.: Diet and serum lipids in atherosclerotic coronary heart disease, Med. Clin. N. Amer. Saunders, Philadelphia, 1963.

306. Jolliffe, N., Baumgartner, L., Rinzler, S. H., Archer, M., Stephenson, J. H., and Christakis, G. J.: The anti-coronary club. The first four years, $N . Y$. St. J. Med. 63, 69, 1963.

307. Dayton, S., Pearce, M. L., Hashimoto, S., Fakler, L. J., Hiscock, E. and Dixon, W. J.: A controlled trial of a diet high in unsaturated fat. Preliminary observations, New Engl.J. Med. 266, 1017, 1962.

308. Baker, B. M., Frantz, I. D., Jr., Keys, A., Kinsell, L. W., Page, I. H., Stamler, J. and Stare, F. J.: The national diet-heart study, J. Amer. med. Ass. 185, 105, 1963.

309. Katz, L. N., Stamler, J. and Pick, R.: Nutrition and Atherosclerosis. Lea \& Febiger, Philadelphia, 1958.

310. StAmLer, J.: Current status of the dietary prevention and treatment of atherosclerotic coronary heart disease, Progr. cardiovasc. Dis. 3, 56, 1960.

311. Oliver, M. F.: The significance of elevated plasma lipids in relation to the prevention of ischaemic heart disease, Bull. Wld Hlth Org. 27, 409, 1962.

312. Green, J. G., Brown, H. B., Meredith, A. P. and Page, I. H.: Use of fat-modified foods for serum cholesterol reduction, J. Amer. med. Ass. 183, 5, 1963. 
313. Adelson, S. F. and Keys, A.: Diet and some health characteristics of 123 business and professional men and methods used to obtain the dietary information. Agricultural Research Service, U.S. Dept. of Agriculture, ARS 62-11, 1962.

314. Kagan, A., Dawber, T. R., Kannel, W. B. and Revotskie, N.: The Framingham study: A prospective study of coronary heart disease, Fed.Proc. 21, (Suppl.11), 52, 1962.

315. Morris, J. N., Marr, J. W., Heady, J. A., Mills, G. L. and Pilkington, T. R. E.: Diet and plasma cholesterol in 99 bank men, Brit. med.J. 1, 571, 1963. 